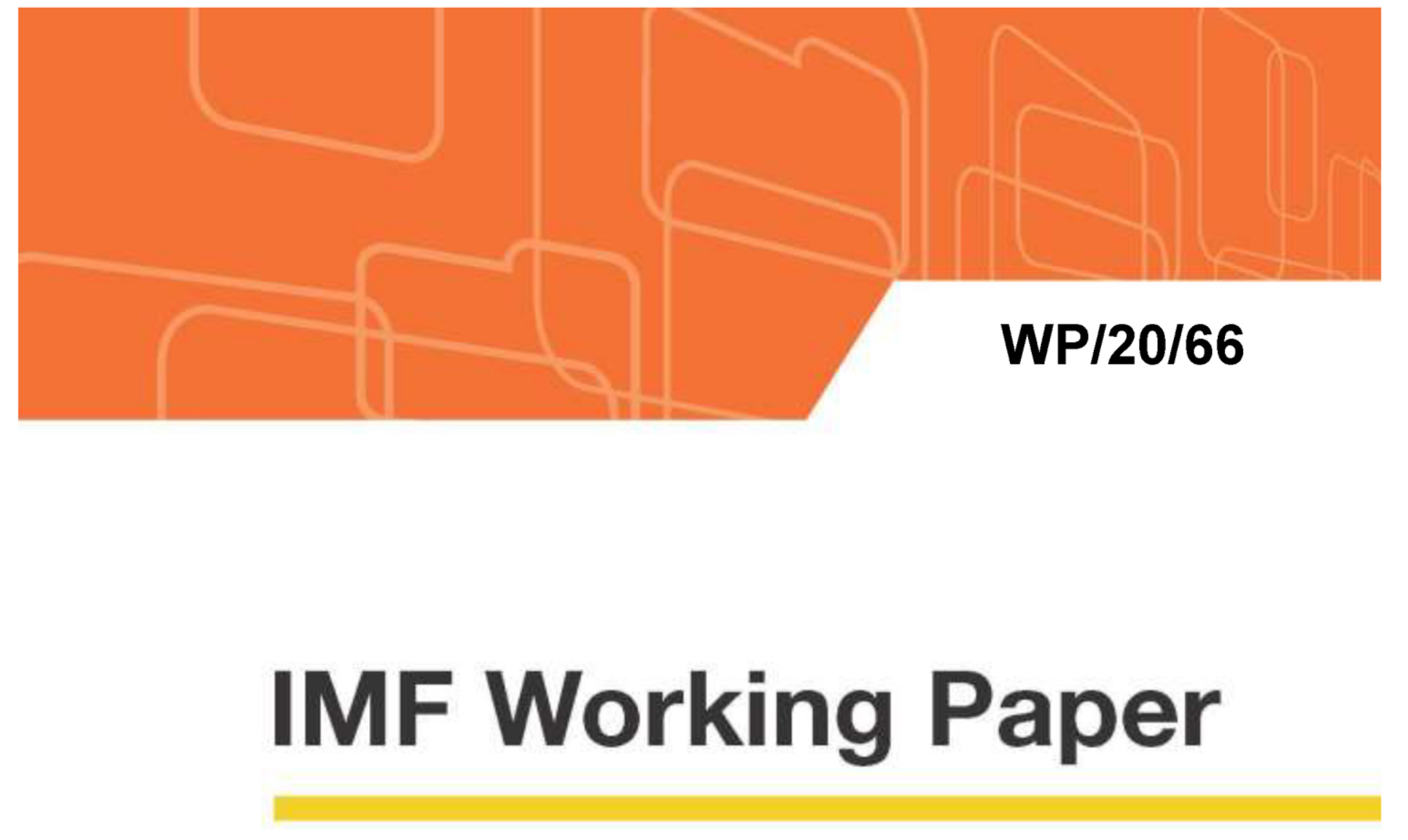

\title{
Do Remittances Enhance Financial Inclusion in LMICs and in Fragile States?
}

by Sami Ben Naceur, Ralph Chami and Mohamed Trabelsi

IMF Working Papers describe research in progress by the author(s) and are published to elicit comments and to encourage debate. The views expressed in IMF Working Papers are those of the author(s) and do not necessarily represent the views of the IMF, its Executive Board, or IMF management. 


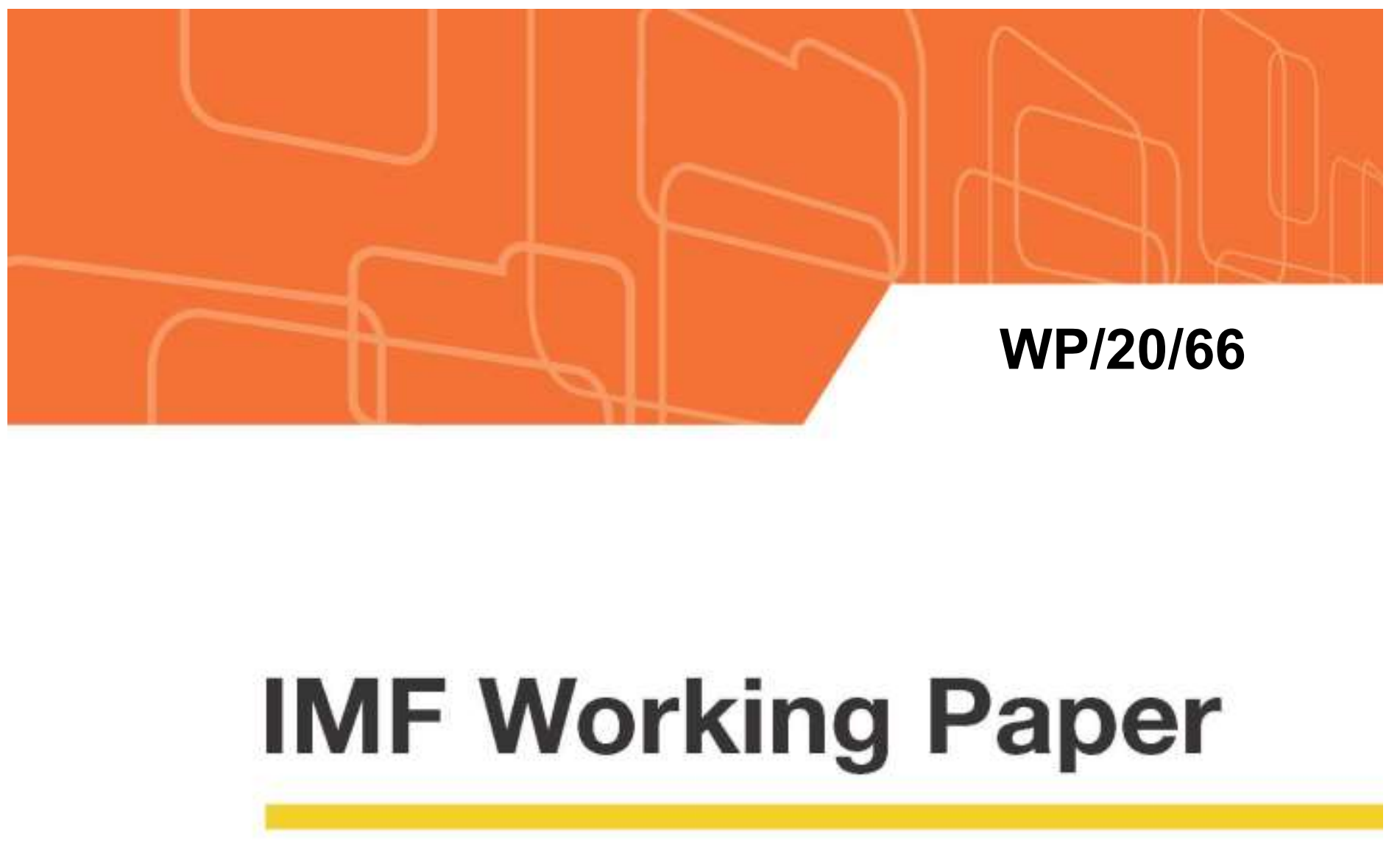

\section{Do Remittances Enhance Financial Inclusion in LMICs and in Fragile States?}

by Sami Ben Naceur, Ralph Chami and Mohamed Trabelsi

IMF Working Papers describe research in progress by the author(s) and are published to elicit comments and to encourage debate. The views expressed in IMF Working Papers are those of the author(s) and do not necessarily represent the views of the IMF, its Executive Board, or IMF management. 


\title{
IMF Working Paper
}

Institute for Capacity Development

\author{
Do Remittances Enhance Financial Inclusion in LMICs and in Fragile States? \\ Prepared by Sami Ben Naceur, Ralph Chami and Mohamed Trabelsi ${ }^{1}$ \\ Authorized for distribution by Ralph Chami
}

May 2020

\section{IMF Working Papers describe research in progress by the author(s) and are published to elicit comments and to encourage debate. The views expressed in IMF Working Papers are those of the author(s) and do not necessarily represent the views of the IMF, its Executive Board, or IMF management.}

\begin{abstract}
This paper explores the relationship between remittances and financial inclusion for a sample of 187 countries over the period 2004-2015, using cross-country as well as dynamic panel GMM regressions. At low levels of remittances-to-GDP, these flows act as a substitute to formal financial channels, thereby reducing financial inclusion. In contrast, when remittance-to-GDP ratio is high, above $13 \%$ on average, they tend to complement formal access and usage channels, thus enhancing financial inclusion. This "U shaped" relationship highlights the role of remittance flows in financing household consumption at low levels, while raising formal household bank savings and allowing for more intermediation, at high levels of remittance-to-GDP.

JEL Classification Numbers: F36, G21, 016

Keywords: Remittances; Financial inclusion; Financial Stability, Financial Development Author's E-Mail Address: sbennaceur@imf.org, rchami@imf.org, mtrabelsi@,imf.org

\footnotetext{
${ }^{1}$ We are grateful to the participants at the 40th annual meeting of the Middle East Economic Association (MEEA) (San Diego, CA, USA, 4-6 January 2020), the International Workshop on Financial System Architecture and Stability (University of Victoria, Victoria, BC, Canada, August 29-30 2019), and at the IMF Institute of Capacity Development (ICD) seminar (Washington DC, USA, January 8, 2019) for helpful comments and suggestions. Special thanks also to Gerard Almekinders, Adolfo Barajas, Majid Bazarbash, Valerie Cerra, and Laura Kodres for constructive remarks. Finally, we are thankful to Basil Awad and Rami Jaradat for technical assistance. Any remaining errors are the sole responsibility of the authors. Financial support for this research from DFID is gratefully acknowledged.
} 


\section{Contents}

I. Introduction

II. Methodology and Data

III. Empirical Results

A. Results

B. Does the Remittance-Recipient Country's Income Level Matter?

C. Does the Remittance-Recipient Country's Level of Financial

Development Matter?

D. Does the Remittance-Recipient Country's Level of Financial Stability Matter?

E. Does the Efficiency of the Remittance-Recipient Country's

Banking Sector Matter?

F. Do Regional Features Matter? $\underline{18}$

G. What About Fragile States?

IV. Conclusion $\underline{22}$

\section{Figures}

1. Inflows into Low and Middle-Income Countries (billions USD), 1990-2018

2. Inflows into Low and Middle-Income Countries (\% of GDP), 1990-2018

3. The Ten Largest Recipients of Remittances (in \% of GDP), 2004-18

4. Differences with Branches

5. Differences with $A T M s$ $\underline{20}$

6. Differences with Deposits $\underline{20}$

7. Differences with Borrowers $\underline{20}$

8. Differences with $F I I$ $\underline{20}$

9. Remittances and Financial Inclusion in Fragile States, OLS Panel Estimates IMF and World Bank Approaches

\section{Tables}

1. Dimensions and Indicators of Financial Inclusion ___ 23

2. Descriptive Statistics 23

3. Correlation Matrix 24 
4. Remittances and Financial Inclusion, GMM Dynamic Panel Estimates for the Whole Sample: 2004-15

5. Remittances and Financial inclusion, GMM Dynamic Panel Estimates: 2004-15___ 26

6. Remittances and Financial Inclusion, GMM Dynamic Panel Estimates of the $\underline{27}$

7. Remittances and Financial Inclusion According to Income Level, GMM Dynamic Panel Estimates of the $\underline{28}$

8. Deposits and Credits in Bank Balance Sheets of LMICS $\underline{29}$

Remittances and Financial Inclusion, the Role of Financial Stability, GMM Dynamic Panel Estimates: 2004-2015 $\underline{30}$

Remittances and Financial Inclusion, the Role of Financial Stability, GMM Dynamic Panel Estimates: 2004-2015 (Continued)

Remittances and Financial Inclusion in LIMCs, the Role of Financial Sector Efficiency___ 32

12. Variable Definitions $\underline{33}$

\section{Appendices}

Appendices

\section{References}

References 


\section{INTRODUCTION}

The recent decade witnessed a substantial increase in remittance inflows to low and middleincome countries (LMICs) reaching 491 USD billion in 2018. Remittances are the second most important source of foreign finance for these countries, ranking second to FDI inflows since 1996, in either percent of GDP or in billions USD, ahead of official aid and portfolio inflows (see Figures 1 and 2). In fact, for low-income countries (LICs), remittance inflows have now surpassed FDIs since 2015.

The increasing importance of remittances has raised interest in studying their development impact. The contributions span several dimensions, including growth (Chami et al., 2015, among others), ${ }^{2}$ poverty (Adams, 2004 and 2006; Acosta et al., 2007, among others), education (Yang, 2008; Adams and Cuecuecha, 2010; and Bredl, 2011), labor supply (Kim, 2007; Rodriguez and Tiongson, 2011; Chami et al., 2018); health (De and Ratha, 2012), and entrepreneurship (Amuedo-Dorantes and Pozo, 2006; Yang, 2008).

Another strand of the literature highlighted the effect of remittances on financial sector development (Martínez Pería, Mascaró, and Moizeszowicz, 2008; Gupta, Pattillo, and Wagh, 2009; Aggarwal, Demirgüç-Kunt, and Martínez Pería, 2011; Chowdhury, 2011; Cooray, 2012, Barajas et al., 2018). This literature suggests that remittances are likely to promote financial development if these flows are transformed into available loanable funds for the private sector through financial intermediaries.

However, it is worth noting that promoting financial development does not necessarily mean that remittances induce more inclusiveness in the financial sector (Anzoategui, DemirgüçKunt and Martínez Pería, 2014). Remittances are likely to improve formal financial access and inclusiveness when unbanked recipient households deposit their money in the financial sector and benefit from the multitudes of financial services offered by formal institutions (Inoue and Hamori, 2016). The topic of financial inclusion has gained importance since it has been integrated in the development agenda by the G20 in 2013. The percentage of people with bank accounts across the world remains relatively low in some regions: 55 percent in East Asia, 39 percent in Latin America, 35 percent in Eastern Europe, 33 percent in South East Asia and 25 percent in Sub Saharan Africa (Aga and Martínez Pería, 2014).

The literature on remittances and financial inclusion follows two strands. The first one comprises papers based on household surveys while the second uses cross-country studies. The literature using household surveys generally finds that remittances are positively and significantly correlated with whether a household has a bank account or savings account, but finds no significant correlation with whether a household requests a loan.

\footnotetext{
${ }^{2}$ On growth, see also Cáceres and Saca (2006), Barajas et al. (2008), Mundaca (2008), Giuliano and RuizArranz (2009), Barajas et al. (2009), and Chami, Hakura and Montiel (2009). On poverty, see Anyanwu and Erhijakpor (2010), Inoue (2011), and Inoue and Hamori (2012).
} 
Anzoategui, Demirgüç-Kunt, and Martínez Pería (2014) uses household level data in El Salvador for the years 1996, 1998, 2000, and 2002 to explore the relationship between remittances and financial inclusion. They find that remittances are positively and significantly correlated with households' use of deposit accounts, but not significantly correlated with their demand and use of formal loans. Aga and Martínez Pería (2014) use World Bank survey data covering 10,000 households in five Sub-Saharan African counties (Burkina Faso, Kenya, Nigeria, Senegal and Uganda) to test the impact of remittances on household financial inclusion. They find that, in the presence of remittances, the probability of opening a bank account increases. Ambrosius and Cuecuecha (2016) uses data from Mexico for 7,572 households for 2002 and 2005 to investigate the effect of remittances on the use of formal and informal financial services. They find that remittances are positively and significantly correlated with the ownership of savings accounts and recent borrowing. However, the authors point out that informal finance seems to play an important role in accounting for the remittances and borrowing nexus, which highlights the deficiencies of the formal banking market. Demirgüç-Kunt, Lopez-Córdova, Martínez Pería, and Woodruff (2011) use municipality level data on the fraction of households receiving remittances in Mexico to investigate the effects of remittances on banking breadth and depth. They find that remittances are positively and significantly correlated with bank branches per capita, bank accounts per capita, and deposits to GDP.

The second strand of the literature focuses on cross-country empirical investigations. Aggarwal, Demirgüç-Kunt, and Martínez Pería (2011) use a panel of 109 countries over the period 1975-2007 to test the effect of remittances on financial development. They find that remittances are positively and significantly correlated with credit and deposits to GDP ratios. Inoue and Hamori (2016) test the impact of remittance inflows on access to formal financial services using a panel data of 38 developing countries in Asia and Oceania over the period 2001-12. The results highlight a robust positive impact of remittances on the branch network of commercial banks. Giuliano and Ruiz-Arranz (2005) use GMM dynamic panel estimations for 73 developing countries over the 1975-2002 to show that remittances are more effective in promoting growth in less financially developed countries. More recently, Tu et al. (2019) examine the nexuses between remittance inflows, financial inclusion, and economic development, using a large sample of countries over the period 2004-17. They find that higher remittances could provide more financial inclusion, which in turn could spur economic development in middle income countries. But, that effect seems to fizzle for high income countries.

In this paper, we attempt to reconcile these differing results, using an empirical model that allows for the presence of a non-monotonic relationship between remittances and financial inclusion. We focus our analysis on low and middle income countries (LMICs), and, to the best of our knowledge, this is a first such attempt at testing for the presence of non-linear relationship between remittance flows and formal financial inclusion. 
We find that that indeed there is a " $U$ " shaped relationship between workers' remittances and financial inclusion. The intuition for this non-monotonic and " $U$ " shaped relationship is that at low levels of remittance-to-GDP, these flows are mainly used for consumption purposes by the liquidity-constrained households operating in countries characterized by credit market imperfections, and this also leads to a process of disintermediation. Mishra et al. (2012) and Barajas et al. (2018) point out that in many LMICs, financial markets are characterized by severe asymmetric information problems, borrower opaqueness, weak legal and institutional frameworks, and oligopolistic banking behavior - all leading to high cost of borrowing and credit rationing. Thus, remittances in this case, by alleviating credit-constraints for the household, are likely to be used by the latter to avoid using the formal financial systemleading to a process of disintermediation. ${ }^{3}$ However, as remittance-to-GDP ratio rises, households are likely to save unused cash flows through the formal channels. Indeed, Barajas et al. (2018) find such evidence in their sample of countries, with time accounts increasing relative to demand deposits, as remittance inflows increase. This in turn allows banks to use such funds to provide financial services. As a result, beyond a certain threshold these flows seem to enhance inclusiveness in the financial sector.

This paper uses a large sample of 187 countries, including low, middle and high-income countries, and Generalized Method of Moments (GMM) regressions over the period 20042015 , to show that financial inclusion starts being positive only when remittances reach the threshold of 13\% of GDP in Low- and Middle-Income Countries (LMICs). This result is consistent with many measures of financial inclusion including the number of commercial bank branches per 100,000 adults (Branches) and Automatic Teller Machines per 100,000 adults (ATMs), the number of deposit accounts in commercial banks per 1,000 adults (Deposits), the average number of borrowers per 1,000 adults (Borrowers), and a weighted Financial Inclusion index (FII). These proxies are considered appropriate for representing financial access (Burgess and Pande, 2005; Beck, Demirgüç-Kunt, and Martínez Pería, 2007) and has little missing observations (Inoue and Hamori, 2016).

This study, to the best of our knowledge, is the first to use such a large sample with heterogenous countries classified according to their income levels. The reason for classification is that LMICs receive most of the remittances while in high income countries remittance flows are much lower than the LMICs average. Furthermore, in contrast to previous studies, this paper uses a macroeconomic approach to address the remittances and financial inclusion nexus; it focuses on the macroeconomic determinants of financial inclusion including remittances as a \% of GDP. Financial inclusion is measured using the number of bank branches, deposits accounts, or borrowers.

The rest of the paper is organized as follows section 2 presents the methodology and discusses the results of the empirical investigation; and section 3 concludes the paper.

\footnotetext{
${ }^{3}$ See Giuliano and Ruiz-Arranz (2005), who find that for low level of remittances, these flows act as substitutes for bank credit.
} 
Figure 1. Inflows into Low and Middle-Income Countries (billions USD), 1990-2018

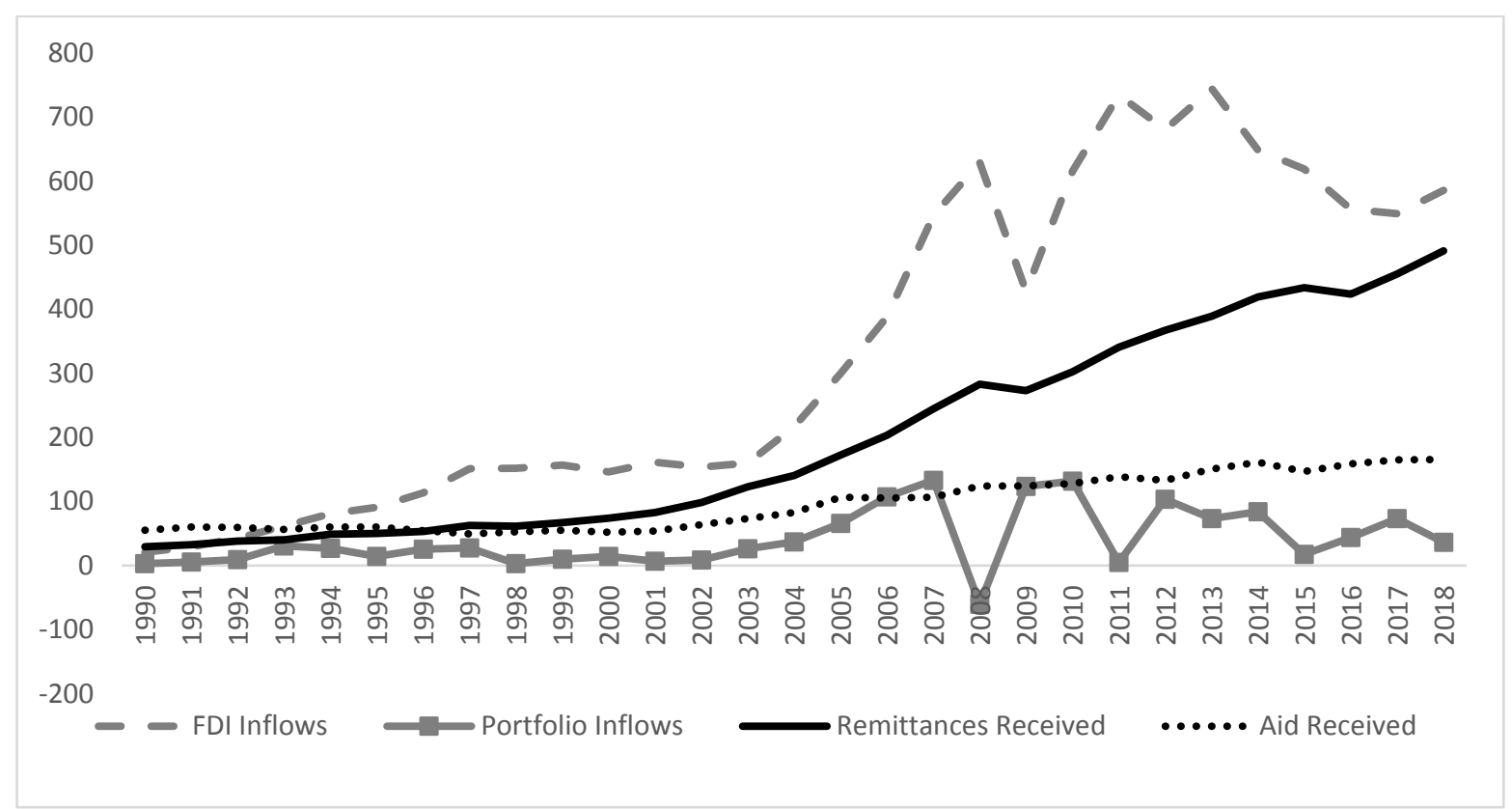

Source: World Development Indicators of the World Bank (2018)

Figure 2. Inflows into Low and Middle-Income Countries (\% of GDP), 1990-2018

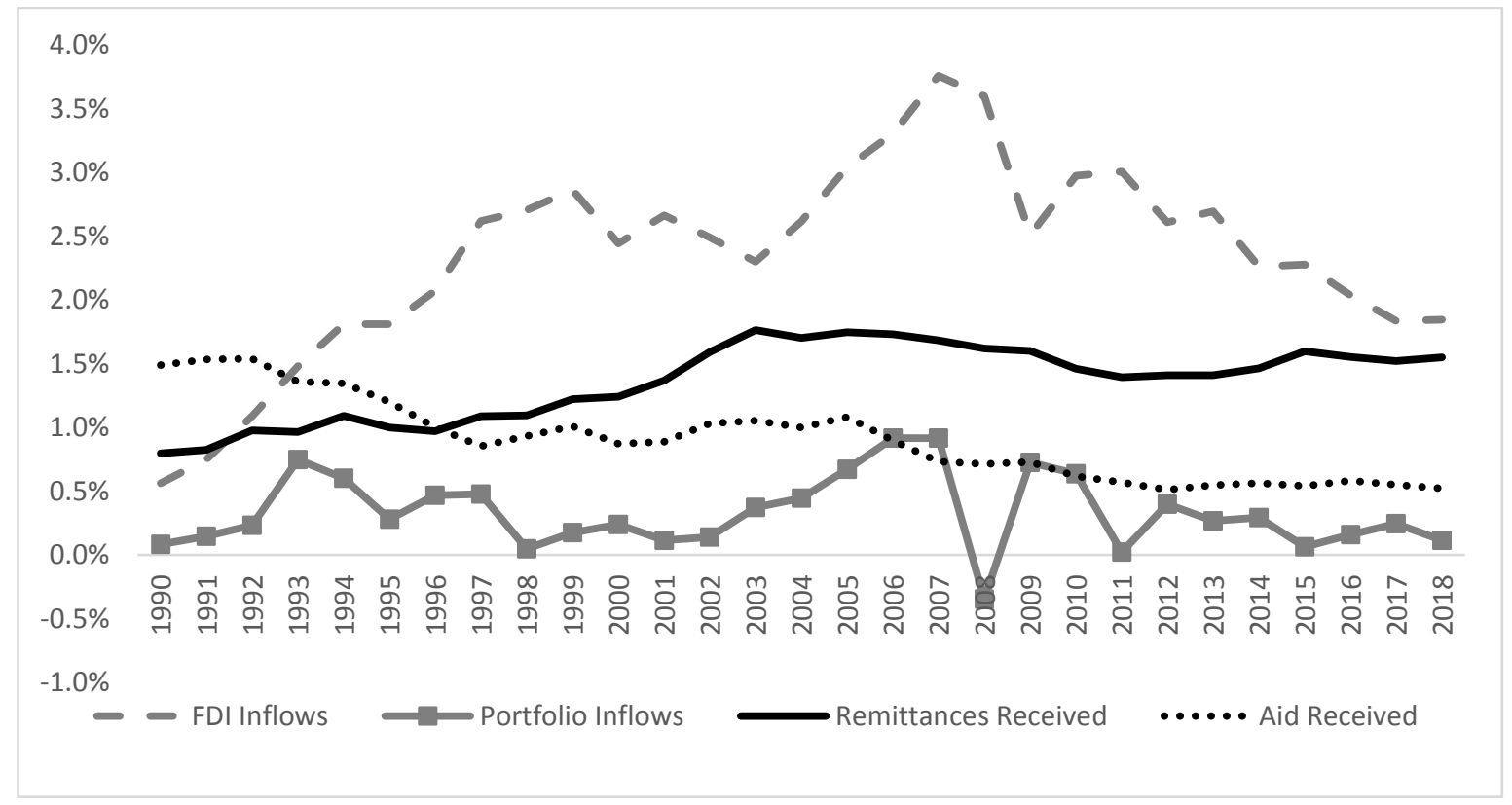

Source: World Development Indicators of the World Bank (2018)

CInternational Monetary Fund. Not for Redistribution 


\section{Methodology ANd DATA}

The empirical relationship between workers' remittances and financial inclusion is based on the following equation:

$$
F I_{i, t}=\alpha+\beta \text { Remit }_{i, t}+\delta X_{i, t}+\mu_{i}+\lambda_{i, t}+\varepsilon_{i, t}
$$

Where $F I_{i, t}$ represents the level of financial inclusion for country $i$ in year $t$, Remit $_{i, t}$ represents remittances received by country $i$ in year $t, X_{i, t}$ represents a vector of control variables, $\mu_{i}$ country- specific effect, $\lambda_{t}$ time specific effect and $\varepsilon_{i, t}$ as an error term. In Table 12 (see Appendices for all Tables) we find the definitions and sources of the all variables used in our estimations, while Table 13 provides the list of countries and periods. Tables 2 and 3 provide descriptive statistics and correlations, respectively.

Following Wang and Guan (2017), we use two dimensions for measures of financial inclusion $(F I)$. The first-dimension deals with the access to financial services with two indicators that assess the outreach of financial services through the demographic penetration of the banking system. The first one is the number (in log) of branches of commercial banks per 100,000 adults (Branches) and the second is the number of ATMs per 100,000 adults (ATMs).

The second dimension reflects the usage that everyone can have of financial services. Indicators of this dimension are the log of deposit accounts with commercial banks per 1,000 adults (Deposits) and the log of the number of borrowers at commercial banks per 1,000 adults (Borrowers). All the measures of Branches, ATMs, Deposits and Borrowers are collected from the Financial Access Survey carried out by the International Monetary Fund as specified in Table 12. The two dimensions (access and usage) and four indicators are summarized in Table 1.

As a last measure of financial inclusion, we use, following Wang and Guan (2017), a financial inclusion index $(F I I)$ based on the above indicators. We start by computing for each dimension $(i=$ Access, Usage $)$ and $F I I$ is calculated as follows:

$$
F I_{i}=1-\frac{\sqrt{\sum_{j=1}^{n} w_{i j}^{2}\left(1-x_{i j}\right)^{2}}}{\sqrt{\sum_{j=1}^{n} w_{i j}^{2}}}
$$

Where $x_{i j}$ is the transformed value of each indicator $j$ relative to dimension $i$ as follows:

$$
x_{i j}=1-\frac{X_{i j}-\operatorname{Min}_{i j}}{\operatorname{Max}_{i j}-\operatorname{Min}_{i j}}
$$


$\mathrm{X}_{\mathrm{ij}}$ is the actual value of the indicators $j$ and Max and Min are the maximum and minimum of $X_{i j}$, respectively. $w_{\mathrm{ij}}$ are the weights of each indicator $j$ relative to each dimension $i$ and is defined as follows:

$$
w_{i j}=\frac{C V_{i j}}{\sum_{j=1}^{n} C V_{i j}}
$$

$\mathrm{CV}$ is the coefficient of variation of the indicator and is defined, following the ratio of standard deviation $(\sigma)$ to the mean value $(\mu)$. Thus, the weights $w_{\mathrm{ij}}$ are defined as the ratio of each indicator's coefficient of variation $\mathrm{CV}$ to the sum of all indicators' $\mathrm{CV}$.

The financial inclusion index for all dimensions $(F I I)$ is therefore as follows:

$$
F I I=1-\frac{\sqrt{w_{1}^{2}\left(1-F I I_{1}\right)^{2}+w_{2}^{2}\left(1-F I I_{2}\right)^{2}}}{\sqrt{w_{1}^{2}+w_{2}^{2}}}
$$

Where $F I I_{1}$ and $F I I_{2}$ are the financial inclusion indices for dimensions 1 and 2 (access and usage). $w_{1}$ and $w_{2}$ are the weights of the two dimensions. Wang and Guan (2017) calculated FII only 2011, while in this paper the effort consists in computing the indices for each year of the period 2004-15. We also exclude the last indicator in Table 1 (Borrowers) from the FII because of data availability.

Workers' remittances are measured as the ratio of remittances inflows to GDP, using the World Development Indicators of the World Bank (2018), and are based on averages for the period 2004-15 and as percentages of GDP. For example, among the largest recipients of remittances, Tajikistan receives 35.0 percent, Bermuda 31.6 percent, Tonga 28.2 percent, and Kyrgyz Republic 22.9 percent (See Figure 3).

The matrix $X$ in equation (1), refers to a set of control variables that are used as regressors. The first one is the logarithm of the GDP per capita (LGDPPC) expressed in 2010 US \$ as a proxy of the level of economic development. This variable is included on the ground that higher income levels would have a positive effect on financial inclusion as it is expected to increase the demand for formal deposits and the available financial instruments in the banking sector (Sahay et al., 2015; Inoue and Hamori, 2016).

The second control variable is inflation and is measured as the percentage annual change of the consumer price index. Higher inflation is expected to push households to rely more on real assets to hedge against financial assets erosion and would end up hindering financial inclusion. This is also the case when it comes to financial deepening (Boyd et al. (2001)). 
Figure 3. The 10 Largest Recipients of Remittances (in \% of GDP), 2004-18

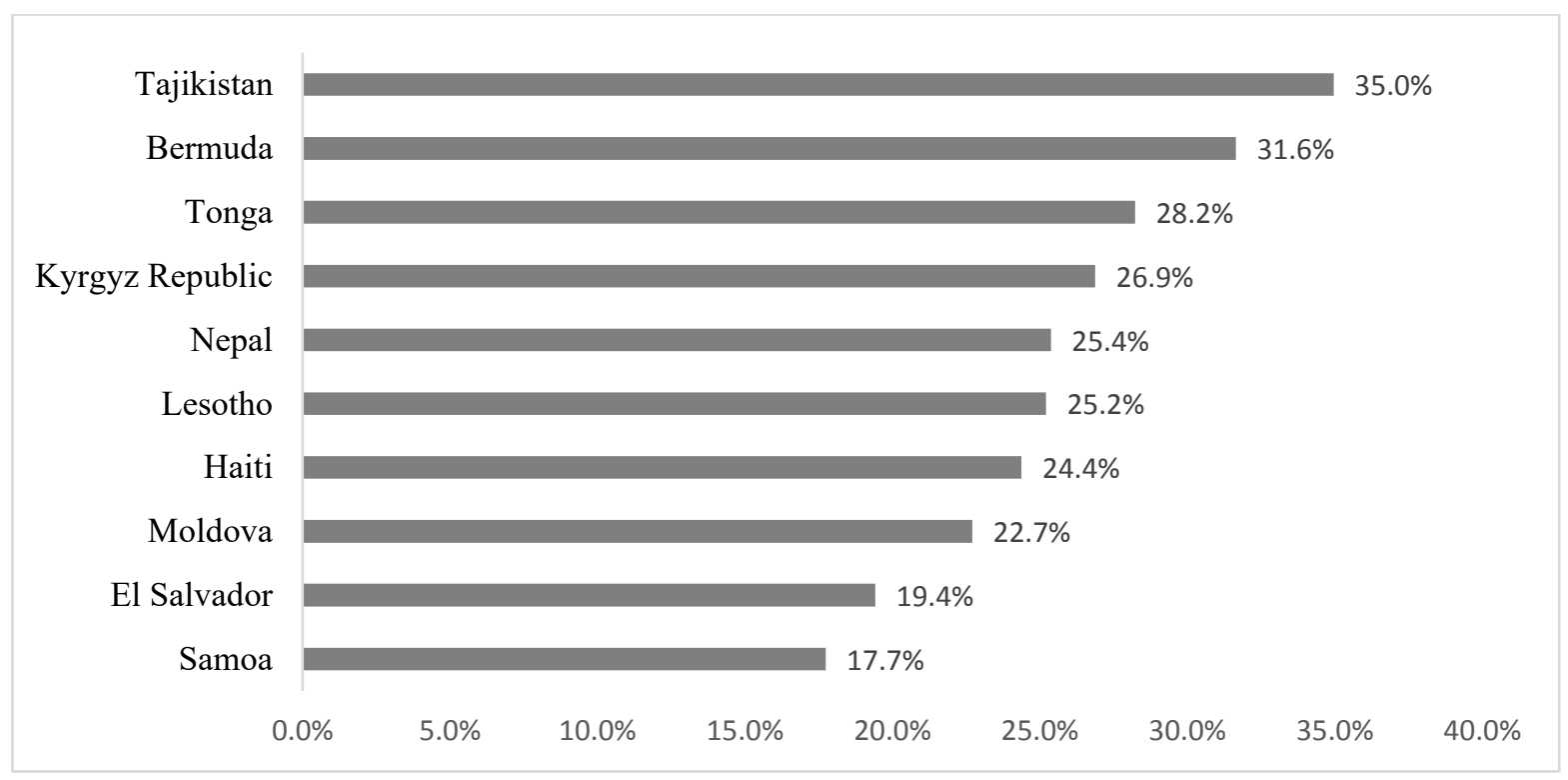

Source: World Development Indicators of the World Bank (2018)

The third regressor included is Trade which is measured as the ratio of the sum of exports and imports to GDP $((\mathrm{X}+\mathrm{M}) / \mathrm{GDP})$. Higher volumes of trade are likely to generate more payments to exporters and importers and create higher demand for financial instruments and more inclusion in the banking sector. Thus, the coefficient of Trade is expected to be positive in equation (1).

The last variable among the regressors is the state of financial openness and is measured by the Chinn and Ito's capital account openness index, generally known with the acronym of kaopen (Chinn and Ito, 2011). This index, initiated by Chinn and Ito (2006), is based on binary dummy variables setting codes on the restrictions on external accounts reported in the IMF's Annual Report on Exchange Arrangements and Exchange Restrictions (AREAER) for each country.

The index takes high values to indicate more openness of the economy to cross-border capital flows. More financial openness is expected to have a positive effect on financial inclusion and any increase in capital inflows in recipient countries is likely to increase the demand for financial products at formal institutions. The literature has already established a positive relationship between capital account liberalization and financial development (Summers, 2000; Klein and Olivei, 2008; Chinn and Ito, 2002; Chinn and Ito, 2006; Eichengreen, Gullapalli and Panizza, 2011).

The estimation of equation (1) is carried out using the dynamic panel GMM techniques, following Inoue and Hamori (2016), Aga and Martínez Pería (2014), Anzoategui, Demirgüç- 
Kunt, and Martínez Pería (2014) and Ambrosius and Cuecuecha (2016). Specifically, we use the GMM estimator in system as follows:

$$
\begin{gathered}
F I_{i, t}=\alpha F I_{i, t-1}+\beta \text { Remit }_{i, t}+\delta X_{i, t}+\mu_{i}+\lambda_{i, t}+\varepsilon_{i, t} \\
\Delta F I_{i, t}=\alpha \Delta F I_{i, t-1}+\beta \Delta \text { Remit }_{i, t}+\delta \Delta X_{i, t}+\Delta \lambda_{i, t}+\Delta \varepsilon_{i, t}
\end{gathered}
$$

Where $F I_{i, t-l}$ is the lagged dependent variable and $\Delta$ is the first difference operator. Equations (6) and (7) are estimated using a GMM panel estimator that combines the regressions in differences with those in levels, following Arellano and Bover (1995) and Blundell and Bond (1998). This estimator uses instruments to deal with the issue of endogeneity of explanatory variables and the correlation between the lagged dependent variable $\left(\Delta F I_{i t-1}=F I_{i, t-1}-F I_{i, t-2}\right)$ and the error term $\left(\Delta \varepsilon_{i t}=\varepsilon_{i, t}-\varepsilon_{i, t-1}\right)$. It is known as a system GMM estimator which improves the efficiency (Blundell, Dearden, Goodman, \& Reed, 2000).

Two tests are used to check for the consistency of the system represented by equations (6) and (7). The first one is the autocorrelation test $\operatorname{AR}(2)$ for the autocorrected disturbances in equation (7). The second test is the validation of the instruments in the GMM system and it is

carried out using the Hanson test of over-identifying restrictions. Finally, the panel used in the empirical investigation is composed of 187 countries over the period 2004-15.

\section{EMPIRICAL RESULTS}

\section{A. Results}

Table 4 displays the GMM dynamic panel estimates using the same proxies of financial inclusion for the whole panel. Column (1) shows the coefficients of the regression with Branches as a measure for financial inclusion. The coefficient of remittances (Remit) is positive $(0.0007)$ and statistically insignificant at standard confidence levels with a robust Hansen test of the overidentifying restrictions $(+0.12)$. This means that higher workers' transfers are not likely to increase the number of commercial banks' branches per 100,000 adults. In other words, more transfers from expats are not found to encourage banking institutions to create more branches to allow recipient households to access more services from these institutions.

The coefficient of the GDP per capita is $(\operatorname{Lgdppc})$ is positive but insignificant at the 99 percent confidence level $(+0.0331)$ which does not confirm the above assumptions about the role of economic activity in boosting financial inclusion. This means that higher income is not likely to increase either the demand for deposits or other financial instruments for investment purposes.

The rest of the variables in column (1) show correct coefficients for inflation where the coefficient is negative and significant at the 1 percent level, confirming the above predictions 
of the literature. Openness to trade is found to have the expected positive effect on financial inclusion as the coefficient of Trade is positive and significant at standard risk levels. This means that allowing enterprises to be more involved in the exchange of commodities and services is likely to increase the demand for financial services from formal financial institutions. In the same vein, the coefficient of financial openness (kaopen) is positive but insignificant meaning that more capital inflows in the recipient countries are not likely to produce higher demand for financial services and more inclusion accordingly.

The second proxy of financial inclusion in the access dimension is ATMs; it is used in column (2). The obtained results show a positive but insignificant coefficient for remittances $(+0.0032)$. In addition, the coefficients of inflation (Inf), trade openness (Trade) and financial openness (Kaopen) are also insignificant at standard risk levels.

Regarding the usage of financial services, the estimations show positive but insignificant effect of remittances on both usage indicators (Deposits and Borrowers in (columns (3) and (4)) at the $10 \%$ level of risk. This means that households' deposits in banks coming from remittances are not likely to develop more financial services linked to savings or loans, which is contradicting the conclusions of Inoue and Hamori (2016) and Ambrosius and Cuecuecha (2016). The picture is not much different when using the financial inclusion index (FII) (column (5)), as the regression does not show a different pattern.

In column (6), the financial inclusion proxy is replaced with financial development $(F D)$ that is measured by total credit to the private sector (\%) of GDP. The objective to test if remittances are likely to have a positive effect on financial development. The estimated coefficient is positive $(+0.4930)$ and significant at the $1 \%$ risk level and is in line with the literature on remittances and financial development nexus (Aggarwal, Demirgüç-Kunt, and Martínez Pería, 2011).

In Table 5, we split the whole sample into two sub-groups as we estimate the impact of remittances on financial inclusion for low- and middle-income countries (LMICS) and highincome countries (HICs). Column (1) shows the regression results carried out for LMICs with branches as a measure of financial inclusion and they look like those obtained with the whole sample $(+0.0003)$. The results for high-income countries (HICs) do not show a different picture as the coefficient of Remit is negative and insignificant at standard risk level (-0.0036). For the rest of financial inclusion proxies, Deposits and Borrowers, the coefficients of remittances are very low $(+0.0001)$ and +0.001 , respectively and insignificant for the case of LMICs. With the financial inclusion index $(F I I)$, the coefficient of remittances is still positive and insignificant for LMICs but turns to be negative in the case of HICs.

Thus, the results of Table 5 are not different when we split the whole sample into low- and middle-income countries (LMICs) and high-income countries (HICs). They point, overall, to an insignificant effect of remittance inflows on all measures of financial inclusion. 
This result may seem surprising as one would expect that remittance flows play a positive role in promoting financial inclusion. Ambrosius and Cuecuecha (2016) claim that "the effect of remittances on access and the use of financial services is not straightforward...In particular, research so far failed to provide a clear picture on whether remittances have positive impact on access to and the use of credit." As mentioned earlier, if receiving households have limited access to formal loans, this result may not be too surprising. In other words, if the households only use these few dollar flows for consumption purposes, then the expected impact on financial inclusion will be very weak or even insignificant.

Thus, to observe a significant effect on financial inclusion there would need to be enough transfers to households through the banking sector, which are then likely to boost savings and help develop financial services for households, allowing them to access more loans. This explanation might be a reason behind the different results between the positive effect of remittances on financial development (Column 6 in Table 4) and the absence of any significant effect on financial inclusion (Ansoategui, Demirgüç-Kunt and Martínez Pería, 2014). In other words, remittances are likely to improve the access to and usage of financial services only if these flows are deposited in the financial sector so that recipient households can benefit from these institutions (Inoue and Hamori, 2016).

In fact, the claim that remittances play the role of a substitute for credit in the sense that when households are credit constrained, they tend to use income transfers from abroad to fill consumption and investment gaps, finds support in the literature, for example Giuliano and Ruiz-Arranz (2005), Calero, Bedi and Sparrow, (2009), and Taylor \& Wyatt, (1996). Thus, because of credit market imperfections, poor households use remittances to overcome liquidity constraints that restrict their access to formal loans to finance investment in physical and human capital.

The role of remittances in boosting the amount of bank deposits also finds support in the literature. Banking institutions have an interest in targeting remittances given that they are a cheap source of deposit flows (see Barajas et al., 2018), and for remittance receiving households they represent unearned income from abroad, which is likely to increase their demand for savings, see for example Aggarwal, Demirgüç-Kunt, and Martínez Pería, 2011; Ashraf, Aycinena, Martínez, Yang, 2015; Barajas et al., 2018).

These conflicting views in the literature provide support for the above explanation of the absence of positive effect of remittance inflows on financial inclusion, when using GMM dynamic panel estimations. The above explanation implies that the effect of remittances on the access and use of financial services could be conditional on some pre-requisites and conditions. Specifically, the idea that a positive effect of remittances on inclusiveness would require enough remittance inflows into the economy, means the possibility of a threshold above which we expect financial inclusion to be increasing with remittances. This means that the relationship between remittances and financial inclusion might be non-linear. This is what we investigate next. 
One way to take into consideration such a threshold is to add the squared remittances ( Remit $\left.^{2}\right)$ to the of determinants of financial inclusion in equations (6) and (7) as follows:

$$
\begin{gathered}
F I_{i, t}=\alpha F I_{i, t-1}+\beta \text { Remit }_{i, t}+\gamma \text { Remit }_{i t}^{2}+\delta X_{i, t}+\mu_{i}+\lambda_{i, t}+\varepsilon_{i, t} \\
\Delta F I_{i, t}=\alpha \Delta F I_{i, t-1}+\beta \Delta \text { Remit }_{i, t}+\gamma \Delta \text { Remit }_{i t}^{2}+\delta \Delta X_{i, t}+\Delta \mu_{i}+\Delta \lambda_{i, t}+\Delta \varepsilon_{i, t}
\end{gathered}
$$

According to the above intuitive explanation, we expect financial inclusion to be increasing with remittances only after a given level of remittances (as a \% of GDP) represents a minimum.

This means that the coefficient of Remit $^{2}$ should be positive while the coefficient of Remit is negative. With such specification, we have a "U" shaped relationship between remittances and financial inclusion, and the remittances threshold Remit $_{i t}^{*}$ is obtained by deriving $F I_{i, t}$ with respect to Remit $_{i, t}$ and will as follows:

$$
\operatorname{Remit}_{i t}^{*}=\frac{\beta}{2 \gamma}
$$

This intuitive explanation should reconcile the two views in the literature presented above. For low levels of remittances $\left(\right.$ Remit $_{i t}<$ Remit $_{i t}^{*}=\frac{\beta}{2 \gamma}$ ), there is a high likelihood that they would serve for consumption purposes for the receiving households without significant effects on financial inclusion, especially when these flows are carried out through informal channels. However, with remittance levels higher than the threshold $\left(\right.$ Remit $_{i t}>$ Remit $_{i t}^{*}=$ $\left.\frac{\beta}{2 \gamma}\right)$, we expect higher savings and access to loans through formal banking institutions and thus higher financial inclusion.

Table 6 displays the results of the GMM dynamic panel estimates of the regressors in equation (6) and (7) augmented with the remittances squared (Remit ${ }^{2}$ ) to reflect the nonmonotonic nature of the relationship between financial inclusion and remittances. The estimates are carried out using all proxies of financial inclusion for the whole panel.

In column (1) we use Branches as a proxy for financial inclusion for the whole sample, and indeed the coefficient of Remit $^{2}$ is positive and statistically significant at the 90 percent confidence level while the coefficient of Remit is negative and statistically significant at the same confidence level. Column (2) displays the estimated coefficient for Remit $^{2}$ with the ATMs as the dependent variable and is similar to those in column (1). The usage dimension indicators of financial inclusion, i.e. Deposits and Borrowers, do not display a different outcome as the coefficients of the quadratic term $\left(\right.$ Remit $\left.^{2}\right)$ are positive and significant at standard confidence levels ((columns (3) and (4)). With the financial inclusion index (FII) in column (5), we find that the coefficients associated with the linear and Quadratic terms are significantly negative and positive, respectively. This means that the relationship between 
financial inclusion and remittances tends to be non-monotonic and convex and takes a " $U$ " shape with a threshold for remittances after which it impacts positively financial inclusion.

The bottom panel of Table 6 reports the standard tests relative to the GMM dynamic panel estimates and shows that all specifications do not reject the null of no second order correlation. Also, the Hanson tests of overidentifying restrictions provide support for the validity of the restrictions. The resulting thresholds from Table 6 estimates for the whole set of countries vary between 11.3 percent and 23.6 percent according to the used proxy for financial inclusion.

\section{B. Does the Remittance-Recipient Country's Income Level Matter?}

To explore the non-monotonic relationship between remittances and financial inclusion according to the level of income of countries, we estimate the determinants of financial inclusion represented by equations (7) and (8) separately for LMICs and HICs. Table 7 displays the output of the estimations for both subgroups.

In column (1) of Table 7, we estimate the quadratic relationship for the LMICs using Branches as a proxy of financial inclusion. The results look like those of Table 6 as the coefficients of the quadratic and linear terms (Remit ${ }^{2}$ and Remit) are positive and negative and significant at the 10 percent risk level, respectively. This tends to corroborate the nonmonotonic nature of the relationship in the case of LMICs with a threshold for remittances standing at a high of 15.7 percent. This means that only beyond such level of 15.7 percent for remittances (as a percent of GDP) in LMICs the relationship has an increasing slope. Regarding high-income countries (HICs), the estimates show that mostly the coefficients of Remit and Remit $^{2}$ are mostly non-significant at standard confidence levels though they display the right sign. This should not be surprising as HICs do not, in general, receive significant levels of remittance flows.

The second measure of financial inclusion (ATMs) in column (3) for LMICs also seems to produce similar results, providing support for the quadratic shape with positive and significant coefficient for Remit $^{2}$ at the 95 percent confidence level. The resulting threshold is also equal to 21.3 percent, and higher than the one in column (1).

In column (5) we use the number of deposit account holders at commercial banks and other resident banks, as a second proxy of financial inclusion (Deposits). The estimates also confirm the above results and the non-monotonic relationship between financial inclusion and remittances especially for LMICs. In fact, the results show that for these countries the threshold is lower than previous cases as it stands at a high of 13.28 percent. This means that only in countries with remittances (as percent of GDP) higher than 13.3 percent financial inclusion will be increasing with remittances. This result is not surprising for this proxy and reflects more the reality of LMICs. Having a high number of deposit account holders means 
that there is a higher probability that they would be used for consumption as well as investment purposes.

Finally, for the second indicator in the usage dimension (Borrowers) in Column 7, the estimates show a similar trend for LMICs as they corroborate the non-monotonic nature of the relationship between financial inclusion and remittances with a threshold standing at a high of 22 percent. The financial inclusion index $(F I I)$ does not show a different picture though the threshold level is lower (13.0 percent). ${ }^{4}$

The results found in Table 7 seems to be corroborated by the data resulting from bank balance sheets. In fact, we display in Table 8, following Barajas et al (2018), the average of time, saving and foreign currency deposits (percent) GDP, demand deposits (DD) and credit to the private sector (CSP) as a percentage of GDP, according to different intervals of remittances. It would seem that more financial inclusion is equivalent to higher financial services by financial institutions, including more Time and saving deposits, which would lead to more loans for recipient households.

Data in Table (8) show that time, saving and foreign currency deposits in financial institutions are decreasing with remittances until the threshold of 12 percent. Starting from the level of 13 percent (Remit $\leq 13 \%$ ), households' behavior changes as type of deposits switches as remittance flows increase, that is, from demand deposits to longer maturity ones. The longer duration of time deposits, in turn, allow banks to provide more credit. This might be considered as a confirmation of the of the " $U$ " shape relationship between remittance inflows and financial inclusion.

\section{Does the Remittance-Recipient Country's Level of Financial Development Matter?}

To test the effect of financial development on the remittances and inclusion nexus, we split the LMICs sample into two sub-groups, less financially developed countries (LFDCs) and more financially developed countries (MFDCs). The LFDCs are economies whose credit to the private sector ratio (\% of GDP) is below the median level while the MFDCs have a higher CPY level than the median ${ }^{5}$. The level of financial development is measured, following, Levine (1997) and De Gregorio and Guidotti (1995) by the credit to the private sector (\% of GDP) (CPY). It is a widely used indicator in the empirical literature as it highlights the role of the banking sector in providing funding to private activities.

\footnotetext{
${ }^{4}$ Countries with remittances-to-gdp higher than 13\% include, for example, Tajikistan (35.0\%), Bermuda (31.6\%), Tonga (28.2\%), Kyrgyz Republic (26.9\%), Nepal (25.4\%), Lesotho (25.2\%), Haiti (24.4\%), Moldova (22.7\%), El Salvador (19.4\%), Samoa (17.7\%), Honduras (17.6\%), Lebanon (17.2\%), Armenia (16.5\%), Kosovo (16.3\%), Syrian Arab Republic (16.3\%), Jamaica (15.9\%), Jordan (14.1\%), Marshall Islands (13.8\%), Liberia (13.8\%), Tuvalu (13.6\%), and West Bank and Gaza (13.1\%), among others.

${ }^{5}$ The median is equal to $26.8 \%$
} 
Table 9 displays the estimates of the non-monotonic relationship for LFDCs and MFDCs. The regressions are carried out with all the proxies of financial inclusion: Branches, ATMs, Deposits, Borrowers and the composite index FII. Column 1 shows the result of the regression using the Branches as dependent variable for LFDCs. The coefficient of remittances is negative and significant at the 10 percent risk level while the quadratic term Remit $_{i t}^{2}$ is not significant. This latter becomes significant at the 90 percent confidence level in Column 2 when the regression is carried out for MFDCs. The picture does change when it comes to the rest of the proxies of financial inclusion, except for Borrowers (Columns 7 and 9) as the coefficients of Remit ${ }_{i t}$ and Remit $_{i t}^{2}$ are significant at standard risk levels and with expected signs.

Thus, the non-monotonic relationship between workers' remittances and financial inclusion tends to be corroborated when the financial system is developed enough to create more financial services for the economy, including new loans and credit facilities for businesses.

\section{Does the Remittance-Recipient Country's Level of Financial Stability Matter?}

To explore whether financial stability matters, we split the LMICs sample into two subsamples composed of less financially stable countries (LFSCs) and more financially stable countries (MFSCs) based on the median of the Z-score financial stability indicator. ${ }^{6}$ LFSCs have lower values of their Z-score than the median of the sample while MFSCs have higher values.

Table 10 shows the GMM dynamic panel regressions for both sub-groups with all financial inclusion proxies. The regressions tend to show that the non-linear relationship tends to be confirmed in countries with more stable financial countries (MFSCs). In fact, the coefficients of the quadratic terms are positive and significant at the 10 percent and 5 percent risk levels, respectively, and vary between 0.0001 and 0.0005 , while the coefficients for the linear term (Remit ${ }_{i t}$ ) are negative and significant at standard risk levels.

\section{E. Does the Efficiency of the Remittance-Recipient Country's Banking Sector Matter?}

In this section we will test whether the efficiency of the financial sector is important in explaining the nonlinear relationship between remittance workers and financial inclusion. We split the LMICs sample between countries with less efficient banking sectors (LEFSs) and those with more efficient banking sectors (MEFSs), according to the median level of the interest rate spread (spread). ${ }^{7}$ This latter is defined as the difference between lending and

\footnotetext{
${ }^{6}$ The $\mathrm{Z}$-score is defined as follows: $\mathrm{Z}=(\mathrm{ROA}+\mathrm{CAP}) / \sigma \mathrm{ROA}$, Where ROA stands for return on Assets and CAP is the capitalization ratio and equal to equity to Assets (Equity/Assets) and $\sigma$ is the standard deviation. The median of the Z-score for the whole sample of countries is equal to 9.62 .

${ }^{7}$ The median of the spread is equal to 6.53 .
} 
deposit interest rates. Thus, for LMICs countries with interest rate gap higher than the median level, they are considered as less efficient, while for countries with a spread lower than the median, they are considered as more financially efficient.

Table 11 displays the results of the GMM dynamic panel regressions of equations (8) and (9) for both sub-samples. In Column 1, we estimate the nonlinear relationship for LEFSS with branches as measure of financial inclusion, but it doesn't show any significant coefficient for either Remit or Remit ${ }^{2}$. However, in LMICs with more efficient banking sectors (Column (2)), the coefficients are significant at standard risk levels and with the expected signs for the quadratic and linear terms. Similar results are also found with access or usage measures of financial inclusion-all confirm the nonlinear result in LIMCs with efficient banking sectors.

Furthermore, if we take into consideration the thresholds, we find that the values are lower in general compared to those Tables 6 and 7). The intuition behind is that when we restrict the sub-sample of LMICs to those endowed with efficient banking sectors, the threshold level of remittances $\left(\right.$ Remit $\left.^{*}\right)$ beyond which remittance inflows have positive effects on financial inclusion should be lower. Efficient banking institutions are likely to make better use of deposits and offer more attractive services that would encourage unbanked recipient households to open accounts and benefit from offered services to start profitable projects. Indeed, the threshold is 10.9 percent with branches and 14.3 percent for borrowers, as measures of financial inclusion, respectively.

\section{F. Do Regional Features Matter?}

In order to analyze the regional features of the relationship workers' remittances and financial inclusion, we follow Chami et al. (2018), and use the approach that removes each region at a time and we calculate the difference between the coefficients of remittances in the LMICs sample (Columns 1, 3, 5, 7 and 9 in Table 7) and the one in the reduced sample. The specified regions are South Asia (SA), Middle East and North Africa (MENA), East Asia and Pacific (EAP), Sub Saharan African countries (SSA) and Latin America \& Caribbean (LAC).

More specifically, we use the estimated coefficients of Remit and Remit ${ }^{2}$ for LMICs with the different financial inclusion proxies to see whether they are higher or lower than the coefficients obtained for each region. Thus, for Remit, ${ }^{2}$ if the resulting difference between the estimated coefficient for LMICs sample and the one for the sample that rules out the region is positive, this means that the exclusion of this latter has lowered the coefficient of Remit $^{2}$. This should point to the importance of the countries in that region in the non-linear relationship between remittances and financial inclusion, if they were added to the sample. For Remit, a negative difference between the coefficients indicates that the region contributes to the effect by lowering the coefficient in absolute value (i.e., making it less negative). All 
estimated coefficients are carried out using dynamic GMM panel approach and they are significant at standard levels.

Figures 4 to 8 show the difference in the coefficients of Remit $^{2}$ and Remit with five proxies of financial inclusion. Red bars, showing differences in coefficients for Remit ${ }^{2}$, are positive for specified regions with most financial inclusion measures. Removing one region at a time and re-estimating provides lower coefficients with respect to the full sample of LMICs and positive differences, accordingly. Blue bars relative to differences in coefficients for Remit are also negative for the same proxies and confirms lower coefficients with reduced sample of countries. This seems to be the case for most regions with ATMs, Borrowers and financial inclusion index $(F I I)$.

However, a closer inspection of figures 4 to 8 across regions reveals the absence of a pattern for Latin American \& Caribbean (LAC) Countries as red bas are not always positive and some of them are absent because of insignificant coefficients with the reduced sample (i.e. with branches and FII proxies of financial inclusion).

In the case of Sub-Saharan African (SSA) countries, the results suggest that this region does not seem to have influence on the non-linear relationship between workers' remittances and financial inclusion.

All in all, the regional analysis of the non-linear relationship between remittances and financial inclusion is indicative of the importance of South Asia (SA) and East Asia \& Pacific (EAP) in accounting for such relationship. Red and blue bars for these two regions with most financial inclusion proxies are positive and negative, respectively. Removing these countries of these from the basic sample of LMICs is likely to reduce key coefficients of the estimated equation. Asian countries in these two regions are well known for their high ratios of workers' remittances to GDP.

\section{G. What About Fragile States?}

This section investigates empirically the relationship between workers' transfers and financial inclusion for fragile states based on equation (1). However, the features of these countries, including the problems of data availability, impose empirical difficulties. Thus, we restrict our investigation to pooled OLS regressions because of lack of data which makes using other developed techniques difficult to achieve. ${ }^{8}$

\footnotetext{
${ }^{8}$ GMM dynamic panel estimations of equation (1) did not bring significant results especially with " $u$ sage" indicators of financial inclusion because of low number of observations. The results are available upon request.
} 


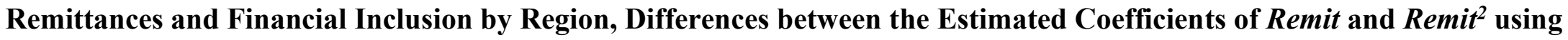
GMM Dynamic Panel: 2004-15

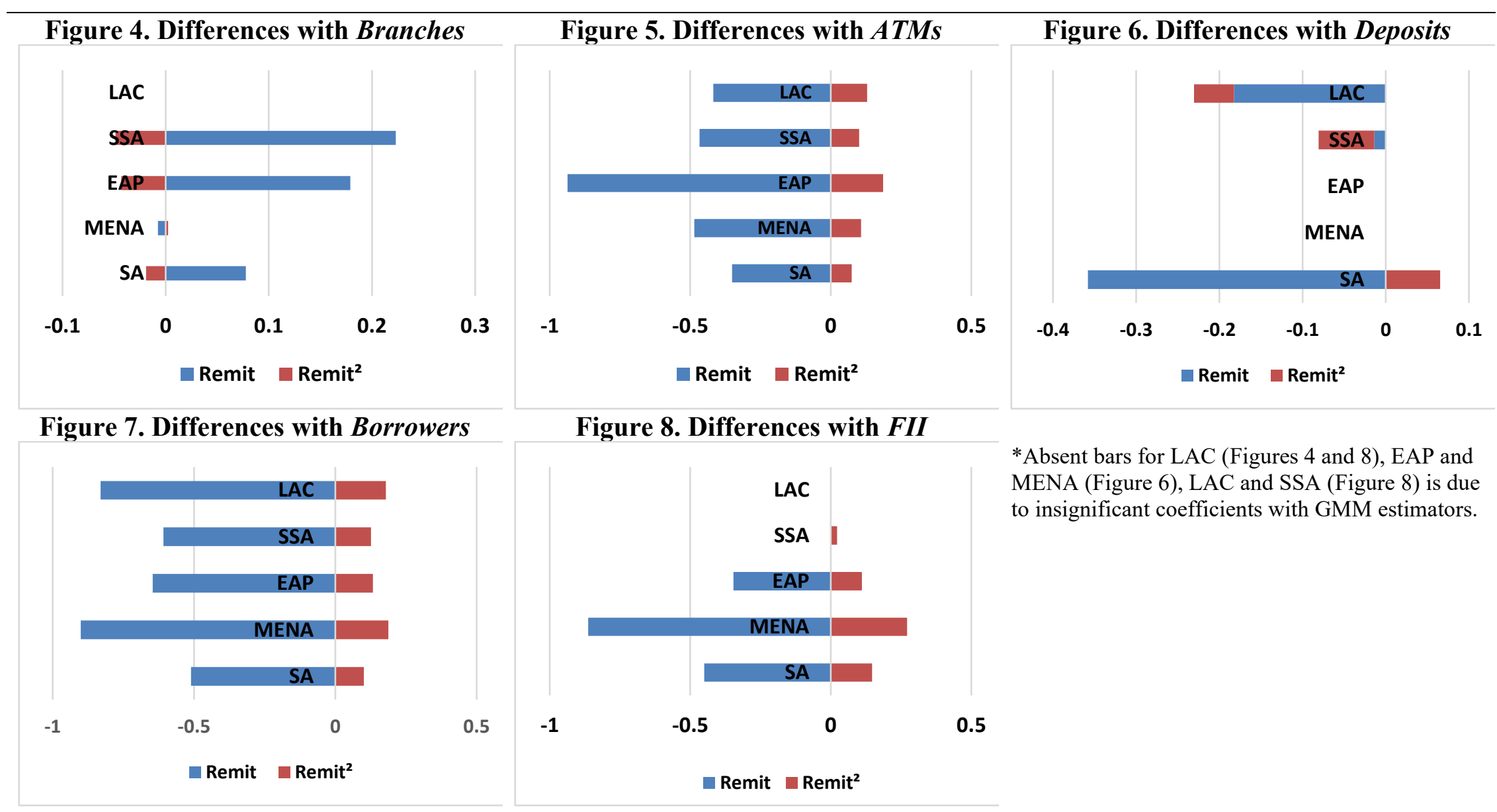


Figure 9 displays the estimated coefficients of Remit using pooled OLS regressions for fragile states using IMF ${ }^{11}$ and World Bank ${ }^{12}$ approaches in defining Fragile states. Blue bars represent the estimated coefficients using the IMF approach in defining fragile countries, while red bars refer to estimated coefficients of World bank approach. The estimations are carried out using all the measures of the financial inclusion.

Results in figure 9 are indicative of a positive effect of remittances on financial inclusion with most indicators. This means that higher remittances contribute to the development of financial services in fragile economies. The negative sign found with the IMF approach as well as the absence of significant effect with the World Bank approach, when using Borrowers as a proxy for financial inclusion, might be explained by the weaknesses of the banking system in these to transform deposits into productive loans.

\section{Figure 9. Remittances and Financial Inclusion in Fragile States, OLS Panel Estimates IMF and World Bank Approaches*}

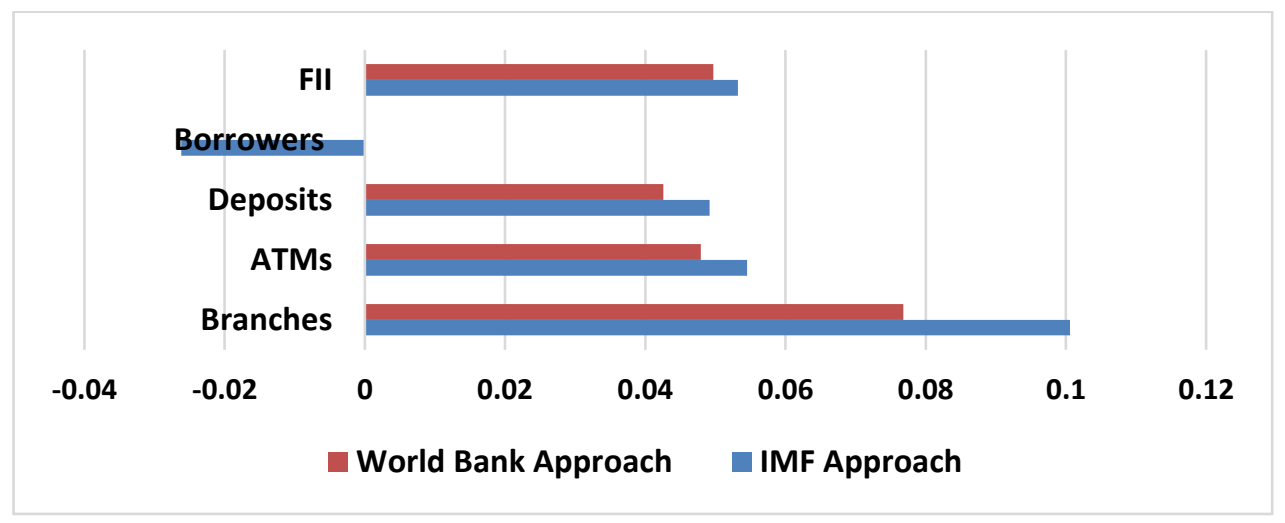

*All coefficients are significant at standard levels except for Borrowers with the World bank approach. Consequently, the red bar is removed.

\footnotetext{
${ }^{11}$ Fragile States are defined here, based on IMF (2017) as having either "weak institutional capacity as measured by weak institutional capacity according to the World Bank's Country Policy and Institutional Assessment (CPIA) score (average of 3.2 or lower) and/or experience of conflict (signaled by presence of a peace-keeping or peace-building operation in the most recent three-year period)," page 8 . Almost 30 percent of IMF members are considered as "fragile" at some point" between 2006 and 2016. At end-2016, there were 39 countries and more than half of them are sub-Saharan African countries.

12 The World Bank approach is based on the "CPIA score against 16 criteria grouped in four clusters: economic management, structural policies, policies for social inclusion and equity, and public-sector management and institutions. Countries eligible for assistance under IDA1 are classified as fragile when they have a rating of 3.2 or less. The maximum score is 6.0," IMF (2017), page 8.
} 


\section{CONCLUSION}

While the development potential of workers' remittances continues to be investigated and debated, the effect of remittances on financial inclusion has not been thoroughly studied. For the most part, the research on the role of remittance flows in enhancing financial inclusion has mainly relied on within country surveys with few papers using cross-country data to tackle this issue.

The main result of the paper is that the relationship between remittances and financial inclusion is nonlinear, and takes a "U" shaped, and that remittances (as percent of GDP) positively impact financial inclusion only beyond a threshold ranging between 22 percent and 12.28 percent in LMICs with more sable, efficient and developed financial sectors. When countries receive low levels of remittances, such flows are used by credit-constrained recipients to smooth their consumption and to avoid having to use formal banking services. Banking services in many of the LMICs and fragile states are costly and may be unavailable to households due to informational and market distortions in such countries. In other words, LMICs countries characterized by low level of financial development, unstable financial sector and oligopolistic banking sectors, low level of remittance flows serves as a substitute to the formal financial sector, as they are a cheaper source of financing.

However, when these income flows are high enough, remittances increase the recipient's households' savings at formal banking institutions. The increase in the maturity of such deposits changes their nature from demand deposits to time deposits, and these, in turn, allow the banks in LMICs to use such funds to provide financial services, including loans. In other words, high remittance inflows, in this case, complement the formal financial services.

This result is robust to using different proxies for financial inclusion and regional distribution of countries, with the nonlinear effect being most significant in East and South Asia and Pacific regions. For fragile states, despite the data difficulty, we are still able to confirm the positive impact of remittances on financial inclusion, for the most part.

Finally, in terms of policy prescription for these countries, it would seem that efforts should focus on maintaining macroeconomic stability, providing regulatory framework that would reduce the cost of formal intermediation, removing distortions in the credit markets, including the pernicious problem of informational asymmetry (such as establishing credit rating bureaus), and on ensuring a more competitive banking system. These efforts are likely to lead to greater financial inclusion. These efforts should also go hand in hand with promoting financial education among the households. 


\section{Appendices}

Table 1. Dimensions and Indicators of Financial Inclusion

\begin{tabular}{|l|l|l|}
\hline \multicolumn{1}{|c|}{ Dimension } & \multicolumn{2}{c|}{ Indicators } \\
\hline Access & Branches & $\begin{array}{l}\text { Branches of commercial banks per 100,000 } \\
\text { adults }\end{array}$ \\
\cline { 2 - 3 } & ATMs & ATMs per 100,000 adults \\
\hline Usage & Deposits & $\begin{array}{l}\text { Deposit accounts with commercial banks per } \\
1,000 \text { adults }\end{array}$ \\
\cline { 2 - 3 } & Borrowers & Borrowers at commercial banks per 1,000 \\
& & adults \\
\hline
\end{tabular}

Table 2. Descriptive Statistics

\begin{tabular}{|l|c|c|c|c|c|}
\hline & Obs. & Mean & Std. Dev & Min & Max \\
\hline Branches & 2108 & 19.54 & 26.69 & 0.12 & 289.83 \\
\hline ATMs & 1947 & 41.40 & 44.32 & 0 & 290.14 \\
\hline Deposits & 1205 & 1110.86 & 1195.67 & 1.25 & 12.420 .85 \\
\hline Borrowers & 973 & 178.00 & 210.70 & 0.01 & 1156.04 \\
\hline FII & 1107 & 0,10 & 0.09 & 0 & 0.69 \\
\hline Remittances & 2060 & 4.71 & 6.85 & 0.00 & 49.28 \\
\hline Log GDP per capita & 2197 & 8.45 & 1.49 & 5.32 & 11.60 \\
\hline Inflation & 2077 & 0.18 & 5.36 & -0.35 & 244.11 \\
\hline Trade & 2121 & 0.93 & 0.54 & 0.00 & 4.55 \\
\hline Kaopen & 1877 & 4.27 & 1.60 & -1.89 & 2.38 \\
\hline
\end{tabular}

Source: Authors' computations. 
Table 3. Correlation Matrix

\begin{tabular}{|l|c|c|c|c|c|c|c|c|c}
\hline & Branches & ATMs & Deposits & Borrowers & FI Index & Remittances & GDP per & Inflation & Trade \\
capita & & & & & \\
\hline Branches & 1.00 & & & & & & & & \\
\hline ATMs & 0.52 & 1.00 & & & & & & \\
\hline Deposits & 0.46 & 0.69 & 1.00 & & & & & \\
\hline Borrowers & 0.40 & 0.70 & 0.75 & 1.00 & & & & \\
\hline FI Index & 0.77 & 0.88 & 0.85 & 0.73 & 1.00 & & & \\
\hline Remittances & -0.01 & -0.17 & -0.03 & -0.13 & -0.08 & 1.00 & & \\
\hline GDP per capita & 0.49 & 0.73 & 0.71 & 0.70 & 0.78 & -0.20 & 1.00 & \\
\hline Inflation & -0.03 & -0.03 & -0.04 & -0.04 & -0.04 & -0.03 & -0.06 & 1.00 & \\
\hline Trade & 0.12 & 0.20 & 0.47 & 0.20 & 0.32 & 0.14 & 0.33 & 0.001 & 1.00 \\
\hline Kaopen & 0.30 & 0.42 & 0.40 & 0.39 & 0.45 & -0.06 & 0.47 & -0.07 & 0.15 \\
\hline
\end{tabular}

Source: Authors' Computations. 
Table 4. Remittances and Financial Inclusion, GMM Dynamic Panel Estimates for the Whole Sample: 2004-15

\begin{tabular}{|c|c|c|c|c|c|c|}
\hline \multicolumn{7}{|c|}{ Dependent variable } \\
\hline & Branches & $A T M s$ & Deposits & Borrowers & $F I I$ & $F D$ \\
\hline & $(1)$ & (2) & (3) & (4) & $(5)$ & (6) \\
\hline L.Branches 1 & $\begin{array}{c}0.9180 * * * \\
(18.55)\end{array}$ & & & & & \\
\hline L.ATMS & & $\begin{array}{c}0.8465 * * * \\
(33.82) \\
\end{array}$ & & & & \\
\hline L.Deposits & & & $\begin{array}{c}0.7815 * * * \\
(12.02) \\
\end{array}$ & & & \\
\hline L.Borrowers & & & & $\begin{array}{c}0.7961 * * * \\
(11.46)\end{array}$ & & \\
\hline L.FII & & & & & $\begin{array}{c}0.7723^{* * *} \\
(15.84)\end{array}$ & \\
\hline L.FD & & & & & & $\begin{array}{c}0.7671 * * * \\
(15.69)\end{array}$ \\
\hline Remit & $\begin{array}{c}0.0007 \\
(0.72) \\
\end{array}$ & $\begin{array}{c}0.0032 \\
(1.09)\end{array}$ & $\begin{array}{c}0.0002 \\
(0.04)\end{array}$ & $\begin{array}{c}0.0013 \\
(0.55) \\
\end{array}$ & $\begin{array}{c}0.0005 \\
(0.14) \\
\end{array}$ & $\begin{array}{c}0.0031 * * * \\
(2.85)\end{array}$ \\
\hline$L G D P P C$ & $\begin{array}{l}0.0331 \\
(0.48)\end{array}$ & $\begin{array}{c}0.0799 * * * \\
(3.35)\end{array}$ & $\begin{array}{c}0.1231^{* *} \\
(2.34)\end{array}$ & $\begin{array}{c}0.1435^{*} \\
(1.82)\end{array}$ & $\begin{array}{c}0.1768^{* * * *} \\
(3.02)\end{array}$ & $\begin{array}{c}0.1214 * * * \\
(3.89)\end{array}$ \\
\hline $\operatorname{Inf}$ & $\begin{array}{c}-0.0259 * * * \\
(-3.00)\end{array}$ & $\begin{array}{r}-0.0001 \\
(-1.38) \\
\end{array}$ & $\begin{array}{c}0.0077 \\
(0.98) \\
\end{array}$ & $\begin{array}{c}-0.0735 * * * \\
(-6.66) \\
\end{array}$ & $\begin{array}{c}-0.0022 * * * \\
(-6.42)\end{array}$ & $\begin{array}{l}-0.2644^{*} \\
(-1.75)\end{array}$ \\
\hline Trade & $\begin{array}{c}0.0463 * \\
(1.79) \\
\end{array}$ & $\begin{array}{r}0.0112 \\
(0.53) \\
\end{array}$ & $\begin{array}{c}0.0651 * \\
(1.80)\end{array}$ & $\begin{array}{c}0.0699 \\
(1.23) \\
\end{array}$ & $\begin{array}{c}0.0773 * * \\
(2.05)\end{array}$ & $\begin{array}{c}0.0423^{*} \\
(1.91)\end{array}$ \\
\hline Kaopen & $\begin{array}{c}0.0086 \\
(0.70) \\
\end{array}$ & $\begin{array}{c}0.0010 \\
(0.10) \\
\end{array}$ & $\begin{array}{c}0.0021 \\
(0.13) \\
\end{array}$ & $\begin{array}{c}0.0005 \\
(0.03) \\
\end{array}$ & $\begin{array}{c}-0.0964 * * * \\
(-2.66) \\
\end{array}$ & $\begin{array}{c}-0.0116 \\
(-1.06) \\
\end{array}$ \\
\hline Constant & $\begin{array}{c}-0.1817 \\
(-0.32) \\
\end{array}$ & $\begin{array}{c}-0.2233 \\
(-1.14) \\
\end{array}$ & $\begin{array}{c}0.3778 * * \\
(2.33) \\
\end{array}$ & $\begin{array}{c}-0.2372 \\
(-0.65) \\
\end{array}$ & $\begin{array}{c}-2.0691 * * * \\
(-3.36) \\
\end{array}$ & $\begin{array}{c}-0.1778 * * * \\
(-1.32) \\
\end{array}$ \\
\hline Observations & 1323 & 1276 & 762 & 558 & 741 & 1450 \\
\hline $\begin{array}{l}\text { AR (2) test. p- } \\
\text { level }\end{array}$ & 0.765 & 0.457 & 0.769 & 0.941 & 0.486 & 0.776 \\
\hline $\begin{array}{c}\text { Hansen test, p- } \\
\text { level }\end{array}$ & 0.120 & 0.121 & 0.385 & 0.362 & 0.222 & 0.508 \\
\hline
\end{tabular}


Table 5. Remittances and Financial inclusion, GMM Dynamic Panel Estimates: 2004-15

\begin{tabular}{|c|c|c|c|c|c|c|c|c|c|c|}
\hline & \multicolumn{10}{|c|}{ Dependent Variable } \\
\hline & \multicolumn{2}{|c|}{ Branches } & \multicolumn{2}{|c|}{$A T M s$} & \multicolumn{2}{|c|}{ Deposits } & \multicolumn{2}{|c|}{ Borrowers } & \multicolumn{2}{|c|}{$F I I$} \\
\hline & LMICs & HICs & LMICs & HICs & LMICs & HICs & LMICs & HICs & LMICs & $\mathrm{HICs}$ \\
\hline & (1) & $(2)$ & (3) & (4) & $(5)$ & $(6)$ & $(7)$ & $(8)$ & (9) & $(10)$ \\
\hline L.Branches & $\begin{array}{c}0.8310 * * * \\
(19.97)\end{array}$ & $\begin{array}{c}0.9976 * * * \\
(59.95)\end{array}$ & & & & & & & & \\
\hline L.ATMS & & & $\begin{array}{c}0.7819 * * * \\
(16.23)\end{array}$ & $\begin{array}{c}0.8376 * * * \\
(16.25)\end{array}$ & & & & & & \\
\hline L.Borrowers & & & & & $\begin{array}{c}0.6165 * * * \\
(12.55)\end{array}$ & $\begin{array}{c}0.9892 * * * \\
(39.54)\end{array}$ & & & & \\
\hline L.Deposits & & & & & & & $\begin{array}{c}0.8274 * * * \\
(10.90)\end{array}$ & $\begin{array}{c}0.8793 * * * \\
(16.54)\end{array}$ & & \\
\hline$L . F I I$ & & & & & & & & & $\begin{array}{c}0.8759 * * * \\
(26.6)\end{array}$ & $\begin{array}{c}0.9632 * * * \\
(24.83)\end{array}$ \\
\hline Remit & $\begin{array}{c}0.0003 \\
(0.14)\end{array}$ & $\begin{array}{c}-0.0182 \\
(-1.18)\end{array}$ & $\begin{array}{c}0.0012 \\
(0.55) \\
\end{array}$ & $\begin{array}{l}-0.0105 \\
(-1.13)\end{array}$ & $\begin{array}{c}0.0001 \\
(0.03)\end{array}$ & $\begin{array}{c}-0.0055 \\
(-0.40)\end{array}$ & $\begin{array}{c}0.0010 \\
(0.40)\end{array}$ & $\begin{array}{c}-0.0207 \\
(-1.25)\end{array}$ & $\begin{array}{c}0.0014 \\
(0.63) \\
\end{array}$ & $\begin{array}{c}-0.0121 \\
(-1.32)\end{array}$ \\
\hline$L G D P P C$ & $\begin{array}{c}0.0571^{*} \\
(1.67)\end{array}$ & $\begin{array}{c}-0.0331 \\
(-0.92)\end{array}$ & $\begin{array}{c}0.1199 * * \\
(2.04)\end{array}$ & $\begin{array}{c}-0.0361 \\
(-0.64)\end{array}$ & $\begin{array}{c}0.2716^{* * * *} \\
(4.93)\end{array}$ & $\begin{array}{c}0.0002 \\
(0.01)\end{array}$ & $\begin{array}{c}0.1458 \\
(1.50)\end{array}$ & $\begin{array}{c}0.0357 \\
(0.61)\end{array}$ & $\begin{array}{c}0.0781 * \\
(1.78)\end{array}$ & $\begin{array}{c}-0.0256 \\
(-1.27)\end{array}$ \\
\hline $\operatorname{Inf}$ & $\begin{array}{c}-0.0426^{* *} \\
(-2.31)\end{array}$ & $\begin{array}{r}0.3115 \\
(1.18) \\
\end{array}$ & $\begin{array}{c}-0.0001 \\
(-0.38) \\
\end{array}$ & $\begin{array}{c}0.2989 \\
(1.09) \\
\end{array}$ & $\begin{array}{c}-0.0027 * * * \\
(-7.71)\end{array}$ & $\begin{array}{c}0.2471 \\
(1.24)\end{array}$ & $\begin{array}{c}-0.0616 * * * \\
(-6.68)\end{array}$ & $\begin{array}{c}-0.0015 \\
(-1.17) \\
\end{array}$ & $\begin{array}{c}-0.0017 * * * \\
(-8.45)\end{array}$ & $\begin{array}{c}0.3109 \\
(1.66)\end{array}$ \\
\hline Trade & $\begin{array}{c}-0.0447 \\
(-0.54) \\
\end{array}$ & $\begin{array}{c}0.0001 \\
(0.01)\end{array}$ & $\begin{array}{c}0.0838 \\
(1.30)\end{array}$ & $\begin{array}{c}0.1122^{* *} \\
(2.04)\end{array}$ & $\begin{array}{c}0.1918 * * \\
(2.33)\end{array}$ & $\begin{array}{c}0.0005 \\
(0.01)\end{array}$ & $\begin{array}{c}0.0983 \\
(1.11)\end{array}$ & $\begin{array}{c}0.0005 \\
(1.40)\end{array}$ & $\begin{array}{c}0.0075 \\
(0.28)\end{array}$ & $\begin{array}{c}0.0042 \\
(0.30)\end{array}$ \\
\hline Kaopen & $\begin{array}{c}0.0519 \\
(1.11) \\
\end{array}$ & $\begin{array}{c}-0.0211 \\
(-0.63) \\
\end{array}$ & $\begin{array}{c}0.0146 \\
(1.11)\end{array}$ & $\begin{array}{c}0.0484^{* *} \\
(2.05)\end{array}$ & $\begin{array}{c}0.0201 \\
(0.91) \\
\end{array}$ & $\begin{array}{c}-0.0169 \\
(-0.86) \\
\end{array}$ & $\begin{array}{c}0.0183 \\
(1.07) \\
\end{array}$ & $\begin{array}{c}0.0046 \\
(0.17) \\
\end{array}$ & $\begin{array}{c}0.0044 \\
(0.59) \\
\end{array}$ & $\begin{array}{c}0.0058 \\
(0.55)\end{array}$ \\
\hline Constant & $\begin{array}{c}-0.1685 \\
(-0.66)\end{array}$ & $\begin{array}{l}0.3982 \\
(1.23)\end{array}$ & $\begin{array}{l}-0.3365 \\
(-0.85)\end{array}$ & $\begin{array}{l}1.1096 \\
(2.27)\end{array}$ & $\begin{array}{c}0.1381 \\
(0.53)\end{array}$ & $\begin{array}{c}0.1251 \\
(0.48)\end{array}$ & $\begin{array}{c}-0.3880 \\
(-0.77)\end{array}$ & $\begin{array}{c}0.3115 \\
(0.50)\end{array}$ & $\begin{array}{c}-2.9392 * * \\
(-2.12)\end{array}$ & $\begin{array}{c}0.1752 \\
(0.76)\end{array}$ \\
\hline Observations & 887 & 290 & 874 & 326 & 614 & 128 & 457 & 103 & 553 & 187 \\
\hline AR (2) test. p-level & 0.796 & 0.820 & 0.490 & 0.238 & 0.695 & 0.712 & 0.95 & 0.300 & 0.498 & 0.098 \\
\hline Hansen test, p-level & 0.316 & 0.373 & 0.601 & 0.676 & 0.234 & 0.905 & 0.382 & 0.949 & 0.348 & 0.945 \\
\hline
\end{tabular}


Table 6. Remittances and Financial Inclusion, GMM Dynamic Panel Estimates of the "U" Relationship: 2004-15

\begin{tabular}{|c|c|c|c|c|c|}
\hline & \multicolumn{5}{|c|}{ Dependent Variable } \\
\hline & Branches & $A T M s$ & Deposits & Borrowers & FII \\
\hline & (1) & $(2)$ & (3) & (4) & (5) \\
\hline L.Branches 1 & $\begin{array}{c}0.9431 * * * \\
(46.32)\end{array}$ & & & & \\
\hline L.ATMS & & $\begin{array}{c}0.8491 * * * \\
(22.72)\end{array}$ & & & \\
\hline L.Deposits & & & $\begin{array}{r}0.8122 \\
(12.81)\end{array}$ & & \\
\hline L.Borrowers & & & & $\begin{array}{c}0.8948^{* * * *} \\
(16.10)\end{array}$ & \\
\hline L.FII & & & & & $\begin{array}{c}0.7900^{* * * *} \\
(22.44) \\
\end{array}$ \\
\hline Remit & $\begin{array}{c}-0.0189 * * \\
(-2.14) \\
\end{array}$ & $\begin{array}{c}-0.0208^{* *} \\
(-2.44) \\
\end{array}$ & $\begin{array}{c}-0.0181^{*} \\
(-1.87) \\
\end{array}$ & $\begin{array}{c}-0.0179 * * \\
(2.43) \\
\end{array}$ & $\begin{array}{c}-0.0171^{*} \\
(-1.69) \\
\end{array}$ \\
\hline Remit $^{2}$ & $\begin{array}{c}0.0004^{*} \\
(1.93) \\
\end{array}$ & $\begin{array}{c}0.0005^{* *} \\
(2.20) \\
\end{array}$ & $\begin{array}{c}0.0008^{* *} \\
(2.43) \\
\end{array}$ & $\begin{array}{c}0.0004^{* *} \\
(2.55) \\
\end{array}$ & $\begin{array}{c}0.0007 * * \\
(2.27) \\
\end{array}$ \\
\hline$L G D P P C$ & $\begin{array}{c}-0.0261 \\
(-1.35) \\
\end{array}$ & $\begin{array}{r}0.0333 \\
(0.94) \\
\end{array}$ & $\begin{array}{c}0.0881^{*} \\
(1.71)\end{array}$ & $\begin{array}{r}0.0281 \\
(0.51) \\
\end{array}$ & $\begin{array}{c}0.1125^{* * * *} \\
(3.21) \\
\end{array}$ \\
\hline $\operatorname{Inf}$ & $\begin{array}{c}-0.0004 \\
(-0.91) \\
\end{array}$ & $\begin{array}{c}-0.0007 * * * \\
(-3.18)\end{array}$ & $\begin{array}{l}0.0010 \\
(0.14)\end{array}$ & $\begin{array}{c}-0.0666^{* * *} \\
(-6.12) \\
\end{array}$ & $\begin{array}{c}-0.1188 \\
(-0.43) \\
\end{array}$ \\
\hline Trade & $\begin{array}{c}0.0456^{*} \\
(1.69)\end{array}$ & $\begin{array}{c}0.0129 \\
(0.53) \\
\end{array}$ & $\begin{array}{c}0.0549 * * \\
(2.07)\end{array}$ & $\begin{array}{c}0.0875 \\
(1.62) \\
\end{array}$ & $\begin{array}{l}0.0165 \\
(0.77)\end{array}$ \\
\hline Kaopen & $\begin{array}{c}0.0125 \\
(1.28) \\
\end{array}$ & $\begin{array}{c}0.0159^{*} \\
(1.70)\end{array}$ & $\begin{array}{c}0.0079 \\
(0.60) \\
\end{array}$ & $\begin{array}{l}0.0116 \\
(1.07)\end{array}$ & $\begin{array}{c}0.0046 \\
(0.42) \\
\end{array}$ \\
\hline Constant & $\begin{array}{c}0.3704^{* * * *} \\
(2.17) \\
\end{array}$ & $\begin{array}{l}0.3143 \\
(1.33)\end{array}$ & $\begin{array}{c}0.5239 * * * \\
(3.15) \\
\end{array}$ & $\begin{array}{l}0.3189 \\
(1.31)\end{array}$ & $\begin{array}{c}-1.4430 * * * \\
(-3.63) \\
\end{array}$ \\
\hline Observations & 1266 & 1280 & 762 & 558 & 692 \\
\hline $\begin{array}{c}\text { AR (2) test. p- } \\
\text { level }\end{array}$ & 0.897 & 0.473 & 0.681 & 0.86 & 0.378 \\
\hline $\begin{array}{l}\text { Hansen test, p- } \\
\text { level }\end{array}$ & 0.173 & 0.116 & 0.461 & 0.724 & 0.27 \\
\hline Threshold & $23.6 \%$ & $20.8 \%$ & $11.3 \%$ & $22.4 \%$ & $12.2 \%$ \\
\hline
\end{tabular}


Table 7. Remittances and Financial Inclusion According to Income Level, GMM Dynamic Panel Estimates of the "U" Relationship: 2004-15

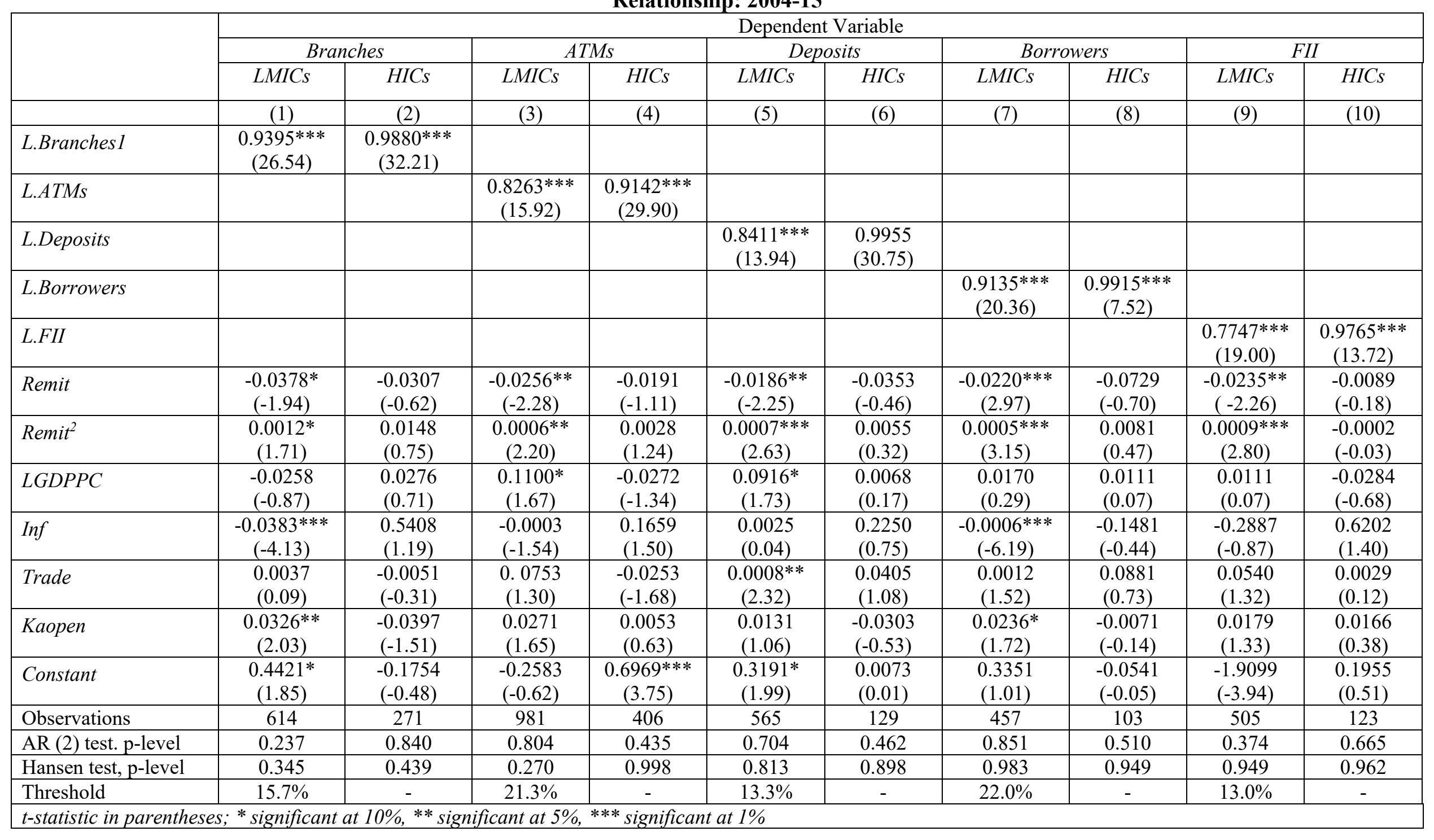


Table 8. Deposits and Credits in Bank Balance Sheets of LMICS

\begin{tabular}{|l|l|l|l|c|}
\hline & $\begin{array}{l}\text { Time, saving } \\
\text { and foreign } \\
\text { currency } \\
\text { deposits }(\%) \\
\text { GDP }\end{array}$ & $\begin{array}{l}\text { Demand } \\
\text { Deposits (\%) } \\
\text { GDP }\end{array}$ & $\begin{array}{l}\text { Total Deposits } \\
(\%) \text { GDP }\end{array}$ & $\begin{array}{l}\text { Total credit as } \\
\text { a (\%) of GDP }\end{array}$ \\
\hline Remit $\leq 1 \%$ & 52.63 & 56.84 & 110.10 & 31.51 \\
\hline Remit $\leq 5 \%$ & 35.67 & 31.49 & 66.77 & 28.77 \\
\hline Remit $\leq 10 \%$ & 33.55 & 27.61 & 61.05 & 29.98 \\
\hline Remit $\leq 11 \%$ & 33.28 & 27.29 & 60.46 & 29.86 \\
\hline Remit $\leq 12 \%$ & 33.01 & 26.94 & 59.83 & 29.76 \\
\hline Remit $\leq \mathbf{1 3 \%}$ & 33.07 & 26.64 & 59.61 & $\mathbf{2 9 . 9 4}$ \\
\hline Remit $\leq 14 \%$ & 33.13 & 26.47 & 59.53 & 29.95 \\
\hline Remit $\leq 15 \%$ & 33.38 & 26.30 & 59.66 & 30.13 \\
\hline Remit $\leq 20 \%$ & 35.91 & 25.35 & 61.29 & 30.97 \\
\hline Remit $\leq 25 \%$ & 37.15 & 24.79 & 61.96 & 31.20 \\
\hline Remit $\leq 30 \%$ & 37.28 & 24.54 & 61.83 & 31.26 \\
\hline
\end{tabular}

Source: Authors Computations 
Table 9. Remittances and Financial Inclusion in LMICs, the Role of Financial Development, GMM Dynamic Panel Estimates: 2004-2015

\begin{tabular}{|c|c|c|c|c|c|c|c|c|c|c|}
\hline & \multicolumn{10}{|c|}{ Dependent Variable } \\
\hline & \multicolumn{2}{|c|}{ Branches } & \multicolumn{2}{|c|}{$A T M s$} & \multicolumn{2}{|c|}{ Deposits } & \multicolumn{2}{|c|}{ Borrowers } & \multicolumn{2}{|c|}{$F I I$} \\
\hline & $L F D C s$ & HFDCs & $L F D C s$ & HFDCs & LFDCs & HFDCs & $L F D C s$ & HFDCs & $L F D C s$ & $H F D C s$ \\
\hline & (1) & $(2)$ & (3) & $(4)$ & $(5)$ & (6) & $(7)$ & (8) & (9) & $(10)$ \\
\hline L.Branches 1 & $\begin{array}{c}0.7826 * * * \\
(10.54)\end{array}$ & $\begin{array}{c}0.9999 * * * \\
(82.53)\end{array}$ & & & & & & & & \\
\hline L.ATMs & & & $\begin{array}{c}0.7913 * * * \\
(11.33)\end{array}$ & $\begin{array}{c}0.8508 * * * \\
(25.54)\end{array}$ & & & & & & \\
\hline L.Deposits & & & & & $\begin{array}{c}0.7745 * * * \\
(8.98)\end{array}$ & $\begin{array}{c}0.9519 * * * \\
(33.70)\end{array}$ & & & & \\
\hline L.Borrowers & & & & & & & $\begin{array}{c}0.6926 * * * \\
(13.47)\end{array}$ & $\begin{array}{c}0.7394 * * * \\
(13.53)\end{array}$ & & \\
\hline L.FII & & & & & & & & & $\begin{array}{c}0.7899 * * * \\
(16.64) \\
\end{array}$ & $\begin{array}{c}0.7567 * * * \\
(9.79)\end{array}$ \\
\hline Remit & $\begin{array}{c}-0.0191 \\
(-1.02) \\
\end{array}$ & $\begin{array}{c}-0.0071 * \\
(-1.98) \\
\end{array}$ & $\begin{array}{c}-0.0139 \\
(-0.96) \\
\end{array}$ & $\begin{array}{c}-0.0147 * * \\
(-2.58) \\
\end{array}$ & $\begin{array}{c}-0.0113 \\
(-0.68) \\
\end{array}$ & $\begin{array}{c}-0.0132 * \\
(-1.84) \\
\end{array}$ & $\begin{array}{c}-0.0341 \\
(-1.46) \\
\end{array}$ & $\begin{array}{c}-0.0117^{*} \\
(-1.78) \\
\end{array}$ & $\begin{array}{c}0.0221^{*} \\
(1.69)\end{array}$ & $\begin{array}{c}-0.0364 * * * \\
(-3.06)\end{array}$ \\
\hline Remit $^{2}$ & $\begin{array}{c}0.0004 \\
(1.06)\end{array}$ & $\begin{array}{c}0.0001 * \\
(1.69)\end{array}$ & $\begin{array}{c}0.0003 \\
(1.12)\end{array}$ & $\begin{array}{c}0.0003^{* *} \\
(2.15)\end{array}$ & $\begin{array}{c}0.0006 \\
(0.93) \\
\end{array}$ & $\begin{array}{c}0.0003^{*} \\
(1.72)\end{array}$ & $\begin{array}{c}0.0008 \\
(1.64)\end{array}$ & $\begin{array}{c}0.0002^{*} \\
(1.96)\end{array}$ & $\begin{array}{c}-0.0006 \\
(-1.37) \\
\end{array}$ & $\begin{array}{c}0.0013 * \\
(3.06)\end{array}$ \\
\hline$L G D P P C$ & $\begin{array}{c}0.0336 \\
(0.60)\end{array}$ & $\begin{array}{c}-0.0255 \\
(-0.91)\end{array}$ & $\begin{array}{c}0.1106^{*} \\
(1.80)\end{array}$ & $\begin{array}{c}0.1047^{*} \\
(1.86)\end{array}$ & $\begin{array}{c}0.1454 * * \\
(2.57)\end{array}$ & $\begin{array}{c}-0.0214 \\
(-0.58)\end{array}$ & $\begin{array}{c}0.2382 * * \\
(2.15)\end{array}$ & $\begin{array}{c}0.1561 * * \\
(2.31)\end{array}$ & $\begin{array}{c}0.1668 * * * \\
(3.73)\end{array}$ & $\begin{array}{c}0.1091 \\
(1.58)\end{array}$ \\
\hline $\operatorname{Inf}$ & $\begin{array}{c}-0.0280 \\
(-0.33) \\
\end{array}$ & $\begin{array}{c}0.0053 \\
(0.45) \\
\end{array}$ & $\begin{array}{c}0.1253 \\
(0.59) \\
\end{array}$ & $\begin{array}{c}-0.0005 \\
(-2.22) \\
\end{array}$ & $\begin{array}{c}0.0785 \\
(1.29) \\
\end{array}$ & $\begin{array}{c}-0.0080 * * \\
(-2.10)\end{array}$ & $\begin{array}{c}-0.1851 \\
(-1.57) \\
\end{array}$ & $\begin{array}{c}-0.0013 \\
(-2.34) \\
\end{array}$ & $\begin{array}{c}0.0798 \\
(0.19) \\
\end{array}$ & $\begin{array}{c}-0.0025 * * * \\
(-9.07)\end{array}$ \\
\hline Trade & $\begin{array}{l}-0.1065 \\
(-1.12) \\
\end{array}$ & $\begin{array}{c}0.0003 \\
(0.01)\end{array}$ & $\begin{array}{c}0.0361 \\
(0.25) \\
\end{array}$ & $\begin{array}{c}0.0714^{*} \\
(1.87)\end{array}$ & $\begin{array}{c}0.0085 \\
(0.11)\end{array}$ & $\begin{array}{c}0.0259 \\
(0.92)\end{array}$ & $\begin{array}{c}0.4440 * \\
(1.91)\end{array}$ & $\begin{array}{c}-0.0246 \\
(-0.37)\end{array}$ & $\begin{array}{c}0.0236 \\
(0.23)\end{array}$ & $\begin{array}{l}-0.0179 \\
(-0.42)\end{array}$ \\
\hline Kaopen & $\begin{array}{c}0.0660 * * \\
(2.02) \\
\end{array}$ & $\begin{array}{c}0.0004 \\
(0.02) \\
\end{array}$ & $\begin{array}{c}0.0408 \\
(1.55)\end{array}$ & $\begin{array}{c}-0.0063 \\
(-0.57) \\
\end{array}$ & $\begin{array}{c}0.0329 \\
(1.27) \\
\end{array}$ & $\begin{array}{c}0.0016 \\
(0.18) \\
\end{array}$ & $\begin{array}{c}0.0694 * \\
(1.72) \\
\end{array}$ & $\begin{array}{c}0.0069 \\
(0.35)\end{array}$ & $\begin{array}{c}0.0042 \\
(0.25) \\
\end{array}$ & $\begin{array}{c}0.0042 \\
(0.25) \\
\end{array}$ \\
\hline Constant & $\begin{array}{c}0.0403 \\
(0.10) \\
\end{array}$ & $\begin{array}{c}0.2812 \\
(1.34)\end{array}$ & $\begin{array}{c}-0.2999 \\
(-0.78) \\
\end{array}$ & $\begin{array}{c}-0.2751 \\
(-0.71) \\
\end{array}$ & $\begin{array}{c}0.2534 \\
(1.09)\end{array}$ & $\begin{array}{c}0.5888 \\
(3.24)\end{array}$ & $\begin{array}{c}-0.8034^{*} \\
(-1.08)\end{array}$ & $\begin{array}{c}0.1584 \\
(0.44) \\
\end{array}$ & $\begin{array}{c}-2.0221^{* *} \\
(-3.94)\end{array}$ & $\begin{array}{c}-1.3287^{*} \\
(-1.72)\end{array}$ \\
\hline Observations & 371 & 463 & 309 & 457 & 247 & 336 & 232 & 247 & 210 & 343 \\
\hline AR (2) test. p-level & 0.959 & 0.344 & 0.262 & 0.282 & 0.978 & 0.587 & 0.302 & 0.202 & 0.382 & 0.219 \\
\hline Hansen test, p-level & 0.668 & 0.467 & 0.812 & 0.337 & 0.956 & 0.810 & 0.989 & 0.945 & 0.994 & 0.708 \\
\hline
\end{tabular}


Table 10. Remittances and Financial Inclusion in LMICs, the Role of Financial Stability, GMM Dynamic Panel Estimates: 2004-15

\begin{tabular}{|c|c|c|c|c|c|c|c|c|c|c|}
\hline & \multicolumn{10}{|c|}{ Dependent Variable } \\
\hline & \multicolumn{2}{|c|}{ Branches } & \multicolumn{2}{|c|}{$A T M s$} & \multicolumn{2}{|c|}{ Deposits } & \multicolumn{2}{|c|}{ Borrowers } & \multicolumn{2}{|c|}{$F I I$} \\
\hline & $L F S C s$ & MFSCs & $L F S C s$ & $M F S C s$ & LFSCS & MFSCs & $L F S C s$ & MFSCs & LFSCS & MFSCs \\
\hline & (1) & $(2)$ & (3) & (4) & $(5)$ & $(6)$ & $(7)$ & $(8)$ & $(9)$ & $(10)$ \\
\hline L.Branches1 & $\begin{array}{c}0.9071 * * * \\
(20.26)\end{array}$ & $\begin{array}{c}0.9916 * * * \\
(72.70)\end{array}$ & & & & & & & & \\
\hline L.ATMs & & & $\begin{array}{c}0.8196 * * * \\
(19.27)\end{array}$ & $\begin{array}{c}0.6540 * * * \\
(6.45)\end{array}$ & & & & & & \\
\hline L.Deposits & & & & & $\begin{array}{c}0.7237 * * * \\
(5.57)\end{array}$ & $\begin{array}{l}0.8762 * * * \\
(11.63)\end{array}$ & & & & \\
\hline L.Borrowers & & & & & & & $\begin{array}{c}0.9128 * * * \\
(25.05)\end{array}$ & $\begin{array}{c}0.9494 * * * \\
(18.87)\end{array}$ & & \\
\hline L.FII & & & & & & & & & $\begin{array}{c}0.9081 * * * \\
(10.78)\end{array}$ & $\begin{array}{c}0.9414 * * * \\
(34.01)\end{array}$ \\
\hline Remit & $\begin{array}{c}-0.0177 \\
(-1.04) \\
\end{array}$ & $\begin{array}{c}-0.0119 * * \\
(-2.53)\end{array}$ & $\begin{array}{c}-0.0063 \\
(-0.76)\end{array}$ & $\begin{array}{c}-0.0227 * * \\
(-2.27)\end{array}$ & $\begin{array}{c}-0.0028 \\
(-0.16)\end{array}$ & $\begin{array}{c}-0.0167^{*} \\
(-1.84)\end{array}$ & $\begin{array}{c}-0.0053 \\
(-0.33) \\
\end{array}$ & $\begin{array}{c}-0.0131^{* *} \\
(-2.22)\end{array}$ & $\begin{array}{l}-0.0118 \\
(-0.90)\end{array}$ & $\begin{array}{c}-0.0058^{*} \\
(-1.67)\end{array}$ \\
\hline Remit $^{2}$ & $\begin{array}{c}0.0004 \\
(1.07) \\
\end{array}$ & $\begin{array}{c}0.0002 * \\
(2.20) \\
\end{array}$ & $\begin{array}{c}0.0002 \\
(1.03) \\
\end{array}$ & $\begin{array}{c}0.0005^{*} \\
(1.93) \\
\end{array}$ & $\begin{array}{c}0.0004 \\
(0.84) \\
\end{array}$ & $\begin{array}{c}0.0005^{* *} \\
(2.11) \\
\end{array}$ & $\begin{array}{c}0.0002 \\
(0.73) \\
\end{array}$ & $\begin{array}{l}0.0003^{* *} \\
(2.25)\end{array}$ & $\begin{array}{c}0.0004 \\
(1.19) \\
\end{array}$ & $\begin{array}{l}0.0002 * \\
(1.71)\end{array}$ \\
\hline$L G D P P C$ & $\begin{array}{c}-0.0090 \\
(-0.25) \\
\end{array}$ & $\begin{array}{c}-0.0440 \\
(-1.36) \\
\end{array}$ & $\begin{array}{c}0.1966^{* * * *} \\
(3.00) \\
\end{array}$ & $\begin{array}{l}0.2377^{*} \\
(1.83)\end{array}$ & $\begin{array}{c}0.2346^{*} \\
(1.84) \\
\end{array}$ & $\begin{array}{c}0.0543 \\
(0.87) \\
\end{array}$ & $\begin{array}{c}0.0380 \\
(0.68) \\
\end{array}$ & $\begin{array}{c}0.0136 \\
(0.23)\end{array}$ & $\begin{array}{c}0.0785 \\
(0.91) \\
\end{array}$ & $\begin{array}{c}0.0167 \\
(0.64) \\
\end{array}$ \\
\hline $\operatorname{Inf}$ & $\begin{array}{c}-0.0332 * * * \\
(-4.12)\end{array}$ & $\begin{array}{l}-0.0332 \\
(-0.36)\end{array}$ & $\begin{array}{c}-0.2182 \\
(-1.00)\end{array}$ & $\begin{array}{l}0.0001 \\
(0.20) \\
\end{array}$ & $\begin{array}{l}0.010 \\
(0.93) \\
\end{array}$ & $\begin{array}{c}-0.0037 * * * \\
(-12.92)\end{array}$ & $\begin{array}{c}-0.0603 * * * \\
(-4.47)\end{array}$ & $\begin{array}{c}0.0456 \\
(0.10) \\
\end{array}$ & $\begin{array}{c}0.1029 \\
(0.32) \\
\end{array}$ & $\begin{array}{c}-0.2176 \\
(-1.14) \\
\end{array}$ \\
\hline Trade & $\begin{array}{c}-0.0145 \\
(-0.24) \\
\end{array}$ & $\begin{array}{c}0.1190 \\
(1.59) \\
\end{array}$ & $\begin{array}{c}0.1047 \\
(1.64) \\
\end{array}$ & $\begin{array}{c}0.0918 \\
(1.06) \\
\end{array}$ & $\begin{array}{c}0.1091 \\
(1.42) \\
\end{array}$ & $\begin{array}{c}0.0554 \\
(1.06) \\
\end{array}$ & $\begin{array}{c}0.0796 \\
(0.81) \\
\end{array}$ & $\begin{array}{r}0.0273 \\
(0.49) \\
\end{array}$ & $\begin{array}{c}0.0303 \\
(0.57) \\
\end{array}$ & $\begin{array}{c}0.0070 \\
(0.27) \\
\end{array}$ \\
\hline Kaopen & $\begin{array}{c}0.0393 * \\
(1.69) \\
\end{array}$ & $\begin{array}{c}-0.0313 \\
(-1.22) \\
\end{array}$ & $\begin{array}{c}-0.0030 \\
(-0.22) \\
\end{array}$ & $\begin{array}{c}0.0305 \\
(1.19) \\
\end{array}$ & $\begin{array}{c}0.0006 \\
(0.03) \\
\end{array}$ & $\begin{array}{c}0.0153 \\
(1.16) \\
\end{array}$ & $\begin{array}{r}0.0257 \\
(1.37) \\
\end{array}$ & $\begin{array}{c}0.0090 \\
(0.72) \\
\end{array}$ & $\begin{array}{c}0.0078 \\
(0.62) \\
\end{array}$ & $\begin{array}{l}-0.0008 \\
(-0.17) \\
\end{array}$ \\
\hline Constant & $\begin{array}{c}0.3215 \\
(1.07) \\
\end{array}$ & $\begin{array}{c}0.4078 \\
(1.49) \\
\end{array}$ & $\begin{array}{c}-0.9666^{* *} \\
(-2.16) \\
\end{array}$ & $\begin{array}{l}-0.8966 \\
(-1.10)\end{array}$ & $\begin{array}{c}-0.1340 \\
(-0.39)\end{array}$ & $\begin{array}{c}0.4072 * * \\
(2.18) \\
\end{array}$ & $\begin{array}{c}0.1603 \\
(0.47) \\
\end{array}$ & $\begin{array}{r}0.2315 \\
(0.66) \\
\end{array}$ & $\begin{array}{c}-0.8037 * \\
(-0.81) \\
\end{array}$ & $\begin{array}{c}-0.2282 \\
(-0.76) \\
\end{array}$ \\
\hline Observations & 457 & 476 & 323 & 443 & 269 & 345 & 244 & 213 & 218 & 230 \\
\hline AR(2) test. p-level & 0.266 & 0.340 & 0.137 & 0.197 & 0.869 & 0.675 & 0.792 & 0.759 & 0.367 & 0.491 \\
\hline Hansen test, p-level & 0.461 & 0.407 & 0.671 & 0.918 & 0.958 & 0.478 & 0.991 & 0.997 & 0.995 & 1.000 \\
\hline
\end{tabular}


Table 11. Remittances and Financial Inclusion in LMICs, the Role of Financial Sector Efficiency-GMM Dynamic Panel Estimates: 2004-2015

\begin{tabular}{|c|c|c|c|c|c|c|c|c|c|c|}
\hline & \multicolumn{10}{|c|}{ Dependent Variable } \\
\hline & \multicolumn{2}{|c|}{ Branches } & \multicolumn{2}{|c|}{$A T M s$} & \multicolumn{2}{|c|}{ Deposits } & \multicolumn{2}{|c|}{ Borrowers } & \multicolumn{2}{|c|}{$F I I$} \\
\hline & LEFSS & MEFSs & LEFSs & $M E F S S$ & LEFSs & $M E F S S$ & LEFSS & MEFSS & LEFSS & MEFSs \\
\hline & (1) & (2) & (3) & (4) & $(5)$ & (6) & (7) & $(8)$ & (9) & (10) \\
\hline L.Branches 1 & $\begin{array}{c}0.8875^{* * * *} \\
(19.30)\end{array}$ & $\begin{array}{c}0.9901 * * * \\
(64.43) \\
\end{array}$ & & & & & & & & \\
\hline L.ATMs & & & $\begin{array}{c}0.7799 * * * \\
(9.17)\end{array}$ & $\begin{array}{c}0.9025 * * * \\
(19.71)\end{array}$ & & & & & & \\
\hline L.Deposits & & & & & $\begin{array}{c}0.7966 \\
(11.25)\end{array}$ & $\begin{array}{l}0.9789 \\
(58.38)\end{array}$ & & & & \\
\hline L.Borrowers & & & & & & & $\begin{array}{c}0.9101 * * * \\
(12.73)\end{array}$ & $\begin{array}{c}0.9887 * * * \\
(26.02)\end{array}$ & & \\
\hline L.FII & & & & & & & & & $\begin{array}{c}0.9100 * * * \\
(21.66)\end{array}$ & $\begin{array}{c}0.9722 * * * \\
(17.76)\end{array}$ \\
\hline Remit & $\begin{array}{l}-0.035 \\
(-0.30)\end{array}$ & $\begin{array}{c}-0.0263 * * \\
(-2.44) \\
\end{array}$ & $\begin{array}{c}-0.0205 \\
(-1.62) \\
\end{array}$ & $\begin{array}{c}-0.0115^{*} \\
(-1.85)\end{array}$ & $\begin{array}{c}-0.0029 \\
(-0.24) \\
\end{array}$ & $\begin{array}{c}-0.0194 * * \\
(-2.05)\end{array}$ & $\begin{array}{c}-0.0119 \\
(-1.29) \\
\end{array}$ & $\begin{array}{c}-0.0086 \\
(-0.73) \\
\end{array}$ & $\begin{array}{r}-0.0032 \\
(-0.19) \\
\end{array}$ & $\begin{array}{c}-0.0083^{* *} \\
(-1.75)\end{array}$ \\
\hline Remit $^{2}$ & $\begin{array}{c}0.0008 \\
(0.33) \\
\end{array}$ & $\begin{array}{c}0.0012^{* *} \\
(2.54)\end{array}$ & $\begin{array}{c}0.0005 * \\
(1.75)\end{array}$ & $\begin{array}{c}0.0003^{*} \\
(1.96)\end{array}$ & $\begin{array}{c}0.0003 \\
(1.15) \\
\end{array}$ & $\begin{array}{c}0.0004^{*} \\
(1.89) \\
\end{array}$ & $\begin{array}{c}0.0003 \\
(1.66)\end{array}$ & $\begin{array}{c}0.0003 \\
(1.09) \\
\end{array}$ & $\begin{array}{c}0.0001 \\
(0.23) \\
\end{array}$ & $\begin{array}{c}0.0002^{*} \\
(2.28) \\
\end{array}$ \\
\hline$L G D P P C$ & $\begin{array}{c}0.0298 \\
(0.87)\end{array}$ & $\begin{array}{c}-0.0187 \\
(-1.15)\end{array}$ & $\begin{array}{c}0.1787 * \\
(1.83)\end{array}$ & $\begin{array}{c}0.0208 \\
(0.37)\end{array}$ & $\begin{array}{c}0.1507 * * \\
(2.36)\end{array}$ & $\begin{array}{c}-0.0552 \\
(-0.93)\end{array}$ & $\begin{array}{c}0.0617 \\
(0.70)\end{array}$ & $\begin{array}{c}-0.0298 \\
(-0.55)\end{array}$ & $\begin{array}{c}0.0643 \\
(1.57)\end{array}$ & $\begin{array}{c}0.0418 \\
(0.64)\end{array}$ \\
\hline $\operatorname{Inf}$ & $\begin{array}{c}-0.0296 * * * \\
(-4.93)\end{array}$ & $\begin{array}{c}-0.3772 * * * \\
(-2.60)\end{array}$ & $\begin{array}{c}-0.0005 \\
(-0.01) \\
\end{array}$ & $\begin{array}{c}0.1522 \\
(1.22)\end{array}$ & $\begin{array}{c}0.0108 \\
(0.97)\end{array}$ & $\begin{array}{c}0.2992 \\
(0.80) \\
\end{array}$ & $\begin{array}{c}0.0002 \\
(1.22)\end{array}$ & $\begin{array}{c}-0.0421 \\
(-0.08)\end{array}$ & $\begin{array}{c}-0.0851 \\
(-0.27)\end{array}$ & $\begin{array}{c}0.4299 \\
(1.66)\end{array}$ \\
\hline Trade & $\begin{array}{c}-0.0722 \\
(-1.03)\end{array}$ & $\begin{array}{r}-0.0631 \\
(-1.57) \\
\end{array}$ & $\begin{array}{c}0.1012 \\
(0.95)\end{array}$ & $\begin{array}{c}0.0545 \\
(1.37) \\
\end{array}$ & $\begin{array}{c}0.0228 \\
(0.41)\end{array}$ & $\begin{array}{c}0.1798 * \\
(1.94)\end{array}$ & $\begin{array}{r}0.0504 \\
(0.69)\end{array}$ & $\begin{array}{c}0.0447 \\
(1.35)\end{array}$ & $\begin{array}{c}0.0063 \\
(0.12) \\
\end{array}$ & $\begin{array}{l}0.0121 \\
(-0.26)\end{array}$ \\
\hline Kaopen & $\begin{array}{c}0.0073 \\
(0.51)\end{array}$ & $\begin{array}{c}0.0159^{*} \\
(1.68) \\
\end{array}$ & $\begin{array}{c}0.0261 \\
(1.31)\end{array}$ & $\begin{array}{c}0.0003 \\
(0.04) \\
\end{array}$ & $\begin{array}{c}0.0055 \\
(0.50)\end{array}$ & $\begin{array}{c}0.0056 \\
(0.50)\end{array}$ & $\begin{array}{c}0.0164 \\
(1.17) \\
\end{array}$ & $\begin{array}{c}0.0082 \\
(0.56)\end{array}$ & $\begin{array}{c}-0.0009 \\
(-0.07) \\
\end{array}$ & $\begin{array}{c}-0.0072 \\
(-0.47)\end{array}$ \\
\hline Constant & $\begin{array}{c}0.0342 \\
(0.14) \\
\end{array}$ & $\begin{array}{c}0.3563^{* *} \\
(2.41)\end{array}$ & $\begin{array}{c}-0.7365 \\
(-1.22) \\
\end{array}$ & $\begin{array}{c}0.2104^{* *} \\
(0.60)\end{array}$ & $\begin{array}{c}0.1055^{*} \\
(0.55)\end{array}$ & $\begin{array}{c}0.5354^{* *} \\
(1.14)\end{array}$ & $\begin{array}{c}0.0121 \\
(0.03) \\
\end{array}$ & $\begin{array}{c}0.3629 \\
(1.05) \\
\end{array}$ & $\begin{array}{c}-0.6879 * * \\
(-1.42)\end{array}$ & $\begin{array}{c}-0.3509 \\
(-0.52) \\
\end{array}$ \\
\hline Observations & 521 & 224 & 475 & 291 & 357 & 208 & 323 & 172 & 312 & 172 \\
\hline AR(2) test. p-level & 0.740 & 0.270 & 0.397 & 0.800 & 0.629 & 0.248 & 0.054 & 0.155 & 0.366 & 0.855 \\
\hline Hansen test, p-level & 0.815 & 0.835 & 0.905 & 0.853 & 0.784 & 0.721 & 0.660 & 0.652 & 0.562 & 0.810 \\
\hline
\end{tabular}


Table 12. Variable Definitions

\begin{tabular}{|c|c|c|}
\hline Variable & Definition and Calculation & Source \\
\hline $\begin{array}{l}\text { Branches of commercial banks } \\
\text { per 100,000 adults (Branches) }\end{array}$ & $\begin{array}{l}\text { Commercial bank branches are retail } \\
\text { locations of resident commercial banks and } \\
\text { other resident banks. }\end{array}$ & $\begin{array}{l}\text { International Monetary } \\
\text { Fund, Financial Access } \\
\text { Survey. }\end{array}$ \\
\hline $\begin{array}{l}\text { Automatic Teller Machines per } \\
100,000 \text { adults }(A T M s)\end{array}$ & $\begin{array}{l}\text { An automated teller machine (ATM) is an } \\
\text { electronic banking outlet, that allows } \\
\text { customers to complete basic transactions, } \\
\text { including dispensing cash and accepting } \\
\text { deposits, without the aid of a branch } \\
\text { representative or teller. }\end{array}$ & $\begin{array}{l}\text { International Monetary } \\
\text { Fund, Financial Access } \\
\text { Survey. }\end{array}$ \\
\hline $\begin{array}{l}\text { Deposit accounts with } \\
\text { commercial banks per } 1,000 \\
\text { adults (Deposits) }\end{array}$ & $\begin{array}{l}\text { Depositors with commercial banks are the } \\
\text { reported number of deposit account holders } \\
\text { at commercial banks and other resident } \\
\text { banks. For many countries, because of lack } \\
\text { of information on account holders, the data } \\
\text { cover the total number of deposit accounts. } \\
\text { The deposits are composed of checking } \\
\text { accounts, savings accounts, and time } \\
\text { deposits. }\end{array}$ & $\begin{array}{l}\text { International Monetary } \\
\text { Fund, Financial Access } \\
\text { Survey. }\end{array}$ \\
\hline $\begin{array}{l}\text { Borrowers at commercial banks } \\
\text { per } 1,000 \text { adults (Borrowers) }\end{array}$ & $\begin{array}{l}\text { Population in urban agglomerations of more } \\
\text { than } 1 \text { million ( } \% \text { of total population) }\end{array}$ & $\begin{array}{l}\text { International Monetary } \\
\text { Fund, Financial Access } \\
\text { Survey. }\end{array}$ \\
\hline Financial Inclusion Index $(F I I)$ & $\begin{array}{l}\text { Composite index based on three indicators } \\
\text { (Branches, ATMs, Deposits) }\end{array}$ & Wang and Guan (2017) \\
\hline Remittances (Remit) & $\begin{array}{l}\text { Personal remittances received (\% of GDP): } \\
\text { Personal remittances are composed of } \\
\text { personal transfers and compensation of } \\
\text { employees. Data are the sum of two items } \\
\text { defined in the sixth edition of the IMF's } \\
\text { Balance of Payments Manual. }\end{array}$ & $\begin{array}{l}\text { World Bank staff } \\
\text { estimates based on IMF } \\
\text { balance of payments } \\
\text { data, and World Bank } \\
\text { and OECD GDP } \\
\text { estimates. }\end{array}$ \\
\hline GDP per capita & $\begin{array}{l}\text { GDP per capita (constant } 2010 \text { US\$): GDP } \\
\text { per capita is gross domestic product divided } \\
\text { by midyear population. Data are in constant } \\
2010 \text { U.S. dollars. }\end{array}$ & $\begin{array}{l}\text { World Bank national } \\
\text { accounts data, and } \\
\text { OECD National } \\
\text { Accounts data files. }\end{array}$ \\
\hline Inflation (Inf) & $\begin{array}{l}\text { The annual change }(\%) \text { of the consumer } \\
\text { price index. }\end{array}$ & $\begin{array}{l}\text { International Monetary } \\
\text { Fund, International } \\
\text { Financial Statistics and } \\
\text { data files. }\end{array}$ \\
\hline Trade Openness (Trade) & $\begin{array}{l}\text { Trade ( } \% \text { of GDP): Trade is the sum of } \\
\text { exports and imports of goods and services } \\
\text { measured as a share of gross domestic } \\
\text { product. }\end{array}$ & $\begin{array}{l}\text { World Bank national } \\
\text { accounts data, and } \\
\text { OECD National } \\
\text { Accounts data files. }\end{array}$ \\
\hline $\begin{array}{l}\text { The financial openness state } \\
\text { (Kaopen) }\end{array}$ & $\begin{array}{l}\text { the Chinn and Ito's capital account } \\
\text { openness index, generally known with the } \\
\text { acronym Kaopen (Chinn and Ito (2011)). }\end{array}$ & (Chinn and Ito (2011)) \\
\hline
\end{tabular}


Table 13. List of Countries and Periods

\begin{tabular}{|c|c|c|c|c|c|}
\hline Country & Years & Country & Years & Country & Years \\
\hline Afghanistan & $2008-2015$ & Guinea & $2004-2015$ & Pakistan & $2004-2015$ \\
\hline Albania & $2004-2015$ & Guinea-Bissau & $2004-2015$ & Palau & $2005-2015$ \\
\hline Algeria & $2004-2015$ & Guyana & $2004-2015$ & Panama & $2004-2015$ \\
\hline Angola & $2008-2015$ & Haiti & $2004-2015$ & Papua New Guinea & $2004-2014$ \\
\hline $\begin{array}{l}\text { Antigua and } \\
\text { Barbuda }\end{array}$ & $2004-2015$ & Honduras & $2004-2015$ & Paraguay & $2004-2015$ \\
\hline Argentina & 2004-2015 & $\begin{array}{l}\text { Hong Kong } \\
\text { SAR, }\end{array}$ & 2004-2015 & Peru & $2004-2015$ \\
\hline Armenia & $2004-2015$ & Hungary & $2004-2015$ & Philippines & $2004-2015$ \\
\hline Aruba & $2004-2011$ & Iceland & $2004-2015$ & Poland & $2004-2015$ \\
\hline Australia & $2004-2015$ & India & 2004-2015 & Portugal & $2004-2015$ \\
\hline Austria & $2004-2015$ & Indonesia & $2004-2015$ & Qatar & $2011-2015$ \\
\hline Azerbaijan & $2004-2015$ & $\begin{array}{l}\text { Iran, Islamic } \\
\text { Rep. }\end{array}$ & 2004-2014 & Romania & $2004-2015$ \\
\hline Bangladesh & $2004-2015$ & Iraq & $2005-2015$ & Russian Federation & $2004-2015$ \\
\hline Barbados & $2004-2015$ & Ireland & $2004-2015$ & Rwanda & $2004-2015$ \\
\hline Belarus & $2004-2015$ & Israel & $2004-2015$ & Samoa & $2004-2015$ \\
\hline Belgium & $2004-2015$ & Italy & $2004-2015$ & $\begin{array}{l}\text { Sao Tome and } \\
\text { Principe }\end{array}$ & $2004-2015$ \\
\hline Belize & $2004-2015$ & Jamaica & $2004-2015$ & Saudi Arabia & $2005-2015$ \\
\hline Benin & $2004-2015$ & Japan & $2004-2015$ & Senegal & $2004-2015$ \\
\hline Bhutan & $2005-2015$ & Jordan & $2004-2015$ & Serbia & $2005-2015$ \\
\hline Bolivia & $2004-2015$ & Kazakhstan & $2004-2015$ & Seychelles & $2004-2015$ \\
\hline $\begin{array}{l}\text { Bosnia and } \\
\text { Herzegovina }\end{array}$ & 2004-2015 & Kenya & 2004-2015 & Sierra Leone & $2004-2015$ \\
\hline Botswana & $2004-2015$ & Kiribati & $2005-2015$ & Slovak Republic & $2004-2015$ \\
\hline Brazil & $2004-2015$ & Korea, Rep. & $2004-2015$ & Slovenia & $2004-2015$ \\
\hline
\end{tabular}




\begin{tabular}{|c|c|c|c|c|c|}
\hline Country & Years & Country & Years & Country & Years \\
\hline Bulgaria & $2004-2015$ & Kosovo & $2004-2015$ & Solomon Islands & $2004-2015$ \\
\hline Burkina Faso & $2004-2015$ & Kuwait & $2010-2015$ & South Africa & $2004-2015$ \\
\hline Burundi & $2004-2015$ & $\begin{array}{l}\text { Kyrgyz } \\
\text { Republic }\end{array}$ & $2004-2015$ & South Sudan & 2014-2014 \\
\hline Cabo Verde & $2004-2015$ & Lao PDR & $2004-2015$ & Spain & $2004-2015$ \\
\hline Cambodia & $2004-2015$ & Latvia & $2004-2015$ & Sri Lanka & $2004-2015$ \\
\hline Cameroon & $2004-2015$ & Lebanon & $2004-2015$ & St. Kitts and Nevis & $2004-2015$ \\
\hline Canada & $2004-2015$ & Lesotho & $2004-2015$ & St. Lucia & $2004-2015$ \\
\hline Chile & $2004-2015$ & Liberia & $2004-2015$ & $\begin{array}{l}\text { St. Vincent and the } \\
\text { Grenadines }\end{array}$ & $2004-2015$ \\
\hline China & $2004-2015$ & Libya & $2004-2011$ & Sudan & $2004-2015$ \\
\hline Colombia & $2004-2015$ & Lithuania & $2004-2015$ & Suriname & $2004-2015$ \\
\hline Comoros & $2004-2015$ & Luxembourg & $2004-2015$ & Swaziland & $2004-2015$ \\
\hline Congo, Dem. Rep. & $2005-2015$ & $\begin{array}{l}\text { Macao SAR, } \\
\text { China }\end{array}$ & $2004-2015$ & Sweden & $2004-2015$ \\
\hline Congo, Rep. & 2004-2007 & $\begin{array}{l}\text { Macedonia, } \\
\text { FYR }\end{array}$ & 2004-2015 & Switzerland & $2004-2015$ \\
\hline Costa Rica & $2004-2015$ & Madagascar & $2004-2015$ & Syrian Arab Republic & $2004-2007$ \\
\hline Cote d'Ivoire & $2004-2015$ & Malawi & $2004-2015$ & Tajikistan & $2004-2015$ \\
\hline Croatia & $2004-2015$ & Malaysia & $2004-2015$ & Tanzania & $2004-2015$ \\
\hline Cyprus & $2004-2015$ & Maldives & $2004-2015$ & Thailand & $2004-2015$ \\
\hline Czech Republic & $2004-2015$ & Mali & $2004-2015$ & Timor-Leste & $2005-2015$ \\
\hline Denmark & $2004-2015$ & Malta & $2004-2015$ & Togo & $2004-2015$ \\
\hline Djibouti & $2004-2015$ & $\begin{array}{l}\text { Marshall } \\
\text { Islands }\end{array}$ & $2005-2015$ & Tonga & $2004-2015$ \\
\hline Dominica & $2004-2015$ & Mauritius & $2004-2015$ & Trinidad and Tobago & $2004-2015$ \\
\hline $\begin{array}{l}\text { Dominican } \\
\text { Republic }\end{array}$ & $2004-2015$ & Mexico & $2004-2015$ & Tunisia & $2004-2015$ \\
\hline
\end{tabular}




\begin{tabular}{|c|c|c|c|c|c|}
\hline Ecuador & 2004-2015 & $\begin{array}{l}\text { Micronesia, } \\
\text { Fed. States }\end{array}$ & $2005-2015$ & Turkey & $2004-2015$ \\
\hline Egypt, Arab Rep. & $2004-2015$ & Moldova & $2004-2015$ & Uganda & $2004-2015$ \\
\hline El Salvador & $2004-2015$ & Mongolia & $2004-2015$ & Ukraine & $2004-2015$ \\
\hline Estonia & $2004-2015$ & Montenegro & $2005-2015$ & United Kingdom & $2004-2015$ \\
\hline Ethiopia & $2004-2015$ & Morocco & $2004-2015$ & United States & $2004-2015$ \\
\hline Fiji & 2004-2015 & Mozambique & $2004-2015$ & Uruguay & $2004-2015$ \\
\hline Finland & $2004-2015$ & Myanmar & $2004-2015$ & Uzbekistan & $2006-2015$ \\
\hline France & $2004-2015$ & Namibia & $2004-2015$ & Vanuatu & $2004-2015$ \\
\hline Gabon & 2004-2015 & Nepal & $2004-2015$ & Venezuela, RB & $2004-2013$ \\
\hline Gambia, The & $2004-2015$ & Netherlands & $2004-2015$ & Vietnam & $2004-2015$ \\
\hline Georgia & 2004-2015 & New Zealand & $2004-2015$ & West Bank and Gaza & $2004-2015$ \\
\hline Germany & 2004-2015 & Nicaragua & $2004-2015$ & Yemen, Rep. & $2004-2015$ \\
\hline Ghana & 2004-2015 & Niger & $2004-2015$ & Zambia & $2004-2015$ \\
\hline Greece & 2004-2015 & Nigeria & $2004-2015$ & Zimbabwe & $2005-2015$ \\
\hline Grenada & $2004-2015$ & Norway & $2004-2015$ & & \\
\hline Guatemala & $2004-2015$ & Oman & $2004-2015$ & & \\
\hline
\end{tabular}




\section{References}

Acosta, P., Pablo, F., and Humberto, L. (2007). The Impact of Remittances on Poverty and Human Capital: Evidence from Latin American Household Surveys. World Bank Policy Research Working Paper, WP 4247.

Adams, R. (2004). Remittances and Poverty in Guatemala. World Bank Policy Research Paper, WP 3418.

Adams, R. (2006). Remittances and Poverty in Ghana. World Bank Policy Research Paper, WP 3838.

Adams, R., and Cuecuecha, A. (2010). Remittances, Household Expenditure and Investment in Guatemala. World Development, 38: 1626-1641.

Aga, G. A., and Martínez Pería, M. S. (2014, July). International Remittances and Financial Inclusion in Sub-Saharan Africa. Policy Research Working Paper \#6991, p. 32 pages.

Aggarwal, R., Demirgüç-Kunt, A., and Martínez-Pería, M. (2011). Do Remittances Promote Financial Development? Journal of Development Economics, 96 (2): 255-64.

Amrosius, C., and Cuecuecha, A. (2016). Remittances and the Use of Formal and Informal Financial Services. World Development, 77: 80-98.

Amuedo-Dorantes, C., and Pozo, S. (2006). Remittance Receipt and Business Ownership in the Dominican Republic. The World Economy, 29 (7): 939-956.

Anyanwu, J., and Erhijakpor, A. (2010). Do International Remittances Affect Poverty in Africa? African Development Review, 22: 828-839.

Anzoategui, D., Demirgüç-Kunt, A., and Martínez Pería, M. (2014). Remittances and Financial Inclusion: Evidence from El Salvador. World Development, 54, 338-349.

Arcand, J., Berkes, E., and Panizza, U. (2012). Too Much Finance? IMF Working Papers $12 / 161$.

Arellano, M., and Bover, O. (1995). Another Look at Instrumental Variables Estimation of Error-Component Models. Journal of Econometrics, 68, 29-51.

Ashraf, N., Aycinena, D., Martinez, C., and Yang, D. (2015). Savings in Transnational Households: A Field Experiment Among Migrants From El Salvador. Review of Economics and Statistics, 97(2): 332-351.

Barajas, A., Chami, R., Cosimano, T., Fullenkamp, C., Gapen, M., and Montiel, P. (2008). Macroeconomic Consequences of Remittances. IMF Occasional Paper 259. 
Barajas, A., Chami, R., Fullenkamp, C., Gapen, M., and Montiel, P. (2009). Do Workers' Remittances Promote Economic Growth? IMF Working Papers 09/153.

Barajas, A., Chami, R., Ebeke, C., and Oeking, A. (2018). What's Different About Monetary Policy Transmission in Remittance-Dependent Countries? Journal of Development Economics, pp. 134 (September): 272-288.

Beck, T., Demirgüç-Kunt, A., and Martínez-Pería, M. (2007). Reaching Out: Access to and Use of Banking Services Across Countries. Journal of Financial Economics, 85(1): 234-66.

Blundell, R., and Bond, S. (1998). Initial Conditions and Moment Restrictions in Dynamic Panel-Data. Journal of Econometrics, 115-143.

Blundell, R., Dearden, L., Goodman, A., and Reed, H. (2000). The Returns to Higher Education in Britain: Evidence From a British Cohort. Journal of Econometrics, 110: F82-F99.

Bredl, S. (2011). Migration, Remittances, and Educational Outcomes: The Case of Haiti. International Journal of Educational Development, 31: 162-168.

Burgess, R., and Pande, R. (2005). Do Rural Banks Matter? Evidence from the Indian Social Banking Experiment. American Economic Review, 95 (3): 780-95.

Cáceres, L. R., and Saca, N. (2006). What Do Remittances Do? Analyzing the Private Remittances Transmission Mechanism in El Salvador. International Monetary Fund Working Paper 06/250.

Calero, C., Bedi, A. S., and Sparrow, R. (2009). Remittances, Liquidity Constraints and Human Capital Investments in Ecuador. World Development, 37: 1143-1154.

Carelo, C., Bedi, A., and Sparrow, R. (2009). Remittances, Liquidity, Constraints, and Human Capital Investments in Ecuador. World Development, 37:1143-1154.

Chami, R., Ekkehard, E., Fullenkamp, C. and Oeking, A. (2018). Are Remittances Good for Labor Markets in LICs, MICs, and Fragile States? Evidence from Cross-Country Data. IMF Working Papers 18/102.

Chami, R., Fullenkamp, C., and Jahjah, S. (2005). Are Immigrant Remittance Flows a Source of Capital for Development? IMF Staff Papers, 52(1): 55-81.

Chami, R., Hakkura, D., and Montiel, P. (2009, April). Remittances: An Automatic Output Stabilizer? IMF Working Papers 09/91. 
Chinn, M., and Ito, H. (2002). Capital Account Liberalization, Institutions, and Economic Growth: Cross-Country Evidence. NBER Working Papers.

Chinn, M., and Ito, H. (2006). What Matters for Financial Development? Capital Controls, Institutions and Interactions. Journal of Development Economics, 81(1), 163-192.

Chinn, M., and Ito, H. (2011). The Chinn-Ito Index- a De Jure Measure of Financial Openness. Retrieved from http://web.pdx.edu/ ito/Chinn-Ito_website.htm.

Chowdhury, M. B. (2011). Remittances Flow and Financial Development in Bangladesh. Economic Modeling, 28 (6): 2600-08.

Cooray, A. (2012). Migrant Remittances, Financial Sector Development and the Government Ownership of Banks: Evidence from a Group of non-OECD Economies. Journal of International Financial Markets, Institutions and Money, 22 (4): 936-57.

De Gregorio, J., and Guidotti, P. (1995). Financial Development and Economic Growth. World Development, 23(3), 433-448.

De, P., and Ratha, D. (2012). Impact of Remittances on Household Income, Asset and Human Capital: Evidence from Sri Lanka. Migration and Development, 1 (1): 163-179.

Demirgüç-Kunt, A., and Maksimovic, V. (1996). Financial Constraints, Uses of Funds, and Firm Growth: An International Comparison. World Bank Policy Research Paper, 1671, 34. Washington, DC: World Bank.

Demirgüç-Kunt, A., Cordova, E. L., Martinez-Peria, M., and Woodruff, C. (2011). Remittances and Banking Sector Breadth and Depth: Evidence from Mexico. Journal of Development Economics, 95 (2): 229-41.

Eichengreen, B., Gullapalli, R., and Panizza, U. (2011). Capital Account Liberalization, Financial Development and Industry Growth: A Synthetic View. Journal of International Money and Finance, 30(6), 1090-1106.

Giuliano, P., and Ruiz Arranz, M. (2005). Remittances, Financial Development, and Growth. IMF Working Papers, 05/234.

Giuliano, P., and Ruiz-Arranz, M. (2009). Remittances. Financial Development, and Growth. Journal of Development Economics, 90: 114-152.

Gupta, S., Pattillo, C. A., and Wagh, S. (2009). Effect of Remittances on Poverty and Financial Development in Sub-Saharan Africa. World Development, 37 (1): 104-15. 
IMF, (2017), Building Fiscal Capacity in Fragile State. Washington DC: International Monetary Fund.

Inoue, T. (2011). Financial Inclusion and Poverty Alleviation in India: An Empirical Analysis Using State-wise Data. In S. Hirashima, H. Oda, and Y. Tsujita, Inclusiveness in India: A Strategy for Growth and Equality (pp. 88-108). Basingstoke, UK and New York: Palgrave Macmillan.

Inoue, T., and Hamori, S. (2012). How has Financial Deepening Affected Poverty Reduction in India? Empirical Analysis Using State-level Panel Data. Applied Financial Economics, 22 (5): 395-408.

Inoue, T., and Homori, S. (2016). Do Workers' Remittances Promote Access to Finance? Evidence from Asia-Pacific Developing Countries. Emerging Markets Finance and Trade, 52: 765-774.

Kim, N. (2007). The Impact of Remittances on Labor Supply: The Case of Jamaica. World Bank Policy Research Working Paper 4120.

Klein, M., and Olivei, J. (2008). Capital Account Liberalization, Financial Depth and Economic Growth. Journal of International Money and Finance, 27, 861-875.

Martínez-Pería, M. S., Mascaró, S. Y., and Moizeszowicz, F. (2008). Do Remittances Affect Recipient Countries' Financial Development? In P. Fajnzylber, and J. H. Lopez, Remittances and Development: Lessons from Latin America (pp. 171-215). Washington, DC: World Bank.

Mishra, P., Montiel, P., and Spilimbergo, A. (2012). Monetary Transmission in Low-Income Countries: Effectiveness and Policy Implications. IMF Economic Review, International Monetary Fund, 60(2): 270-302.

Mundaca, G. (2008). Remittances, Financial Markets Development, and Economic Growth: The Case of Latin America and the Caribbean. Review of Development Economics, 13: 288-303.

Rodriguez, E., \& Tiongson, E. (2001). Temporary Migration Overseas and Household Labor Supply: Evidence from Urban Philippines. International Migration Review, 35 (3): 709-725.

Sahay, R., Cihak, M., P., N., Barajas, A., Mitra, S., Kyobe, A., and Yousefi, S. R. (2015, September). Financial Inclusion: Can It Meet Multiple Macroeconomic Goals? IMF Stuff Discussion Note, SDN/15/17.

Summers, L. (2000). International Financial Crises: Causes, Prevention and Cures. American Economic Review, 90(2), 1-16. 
Tu, C. A., Phi, N. T. M., Tuan, L. Q., Yoshino, N., Sarker, T., and Taghizadeh-Hesary, F. (2019). Remittance Inflows, Financial Inclusion, and Economic Development: An Empirical Analysis of the World Sample. ADBI Working Paper Series \# 1000, Asian Development Bank Institute.

Taylor, E. J., \& Wyatt, T. J. (1996). The Shadow Value of Migrant Remittances, Income and Inequality in a Household-Farm Economy. Journal of Development Studies, 32(6): 899-912.

Wang, X., \& Guan, J. (2017). Financial Inclusion: Measurement, Spatial Effects and influencing Factors. Applied Economics, 49:18, 1751-1762.

World Bank. (2016). World Development Indicators. Washington, DC: World Bank.

World Bank. (2018). World Development Indicators. Washington, DC: World Bank.

Yang, D. (2008). International Migration, Remittances, and Household Investment: Evidence from Philippines Migrants' Exchange Rate Shocks. The Economics Journal, 118: 591-630. 